\title{
Cross-Border Bank Flows and Monetary Policy
}

Correa, Ricardo, Teodora Paligorova, Horacio Sapriza, and Andrei Zlate
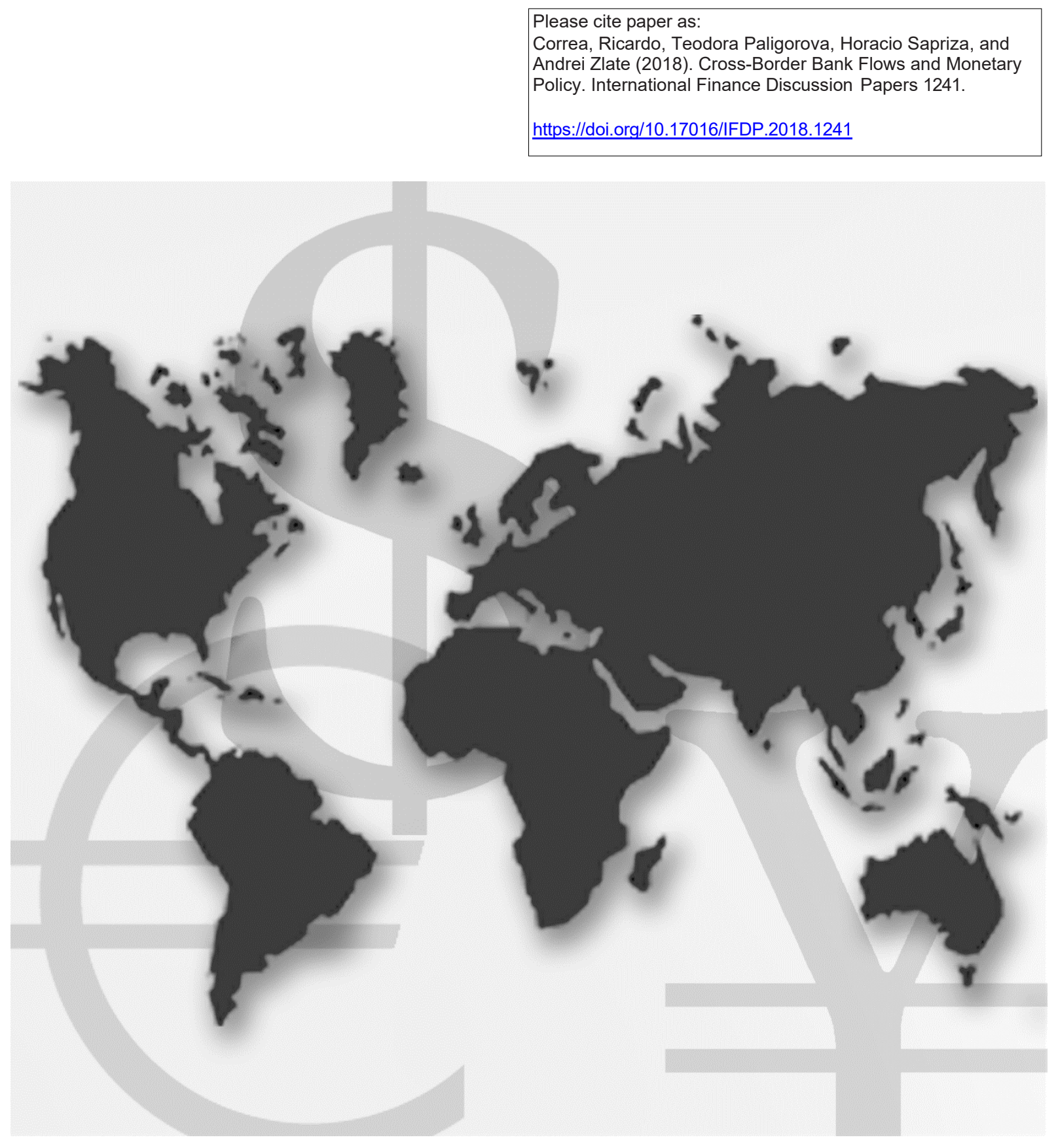

\section{International Finance Discussion Papers}

Board of Governors of the Federal Reserve System

Number 1241

December 2018 
Board of Governors of the Federal Reserve System

International Finance Discussion Papers

Number 1241

December 2018

\section{Cross-Border Bank Flows and Monetary Policy}

Ricardo Correa, Teodora Paligorova, Horacio Sapriza, and Andrei Zlate

NOTE: International Finance Discussion Papers are preliminary materials circulated to stimulate discussion and critical comment. References to International Finance Discussion Papers (other than an acknowledgment that the writer has had access to unpublished material) should be cleared with the author or authors. Recent IFDPs are available on the Web at www.federalreserve.gov/pubs/ifdp/. This paper can be downloaded without charge from the Social Science Research Network electronic library at www.ssrn.com. 


\title{
Cross-Border Bank Flows and Monetary Policy
}

\author{
Ricardo Correa* \\ Federal Reserve Board \\ E-mail: ricardo.correa@frb.gov \\ Teodora Paligorova \\ Federal Reserve Board \\ E-mail: teodora.paligorova@frb.gov \\ Horacio Sapriza \\ Federal Reserve Board \\ E-mail: horacio.sapriza@frb.gov \\ Andrei Zlate \\ Federal Reserve Bank of Boston \\ E-mail: andrei.zlate@bos.frb.org
}

November 14, 2018

JEL classification: E52, F34, F36, G21

Keywords: bank lending, cross-border bank flows, monetary policy, portfolio rebalancing

\footnotetext{
*We thank Jason Allen, Greg Bauer, Allen Berger, Falk Brauning, Mark Carey, Luis Catao, Stijn Claessens, Juan Contreras, Sally Davies, Gaston Gelos, Linda Goldberg, John Kandrac, Vasso Ioannidou, Seung Lee, Andrew Levin, Marco Lo Duca, Patrick McGuire, Camelia Minoiu, Josef Schroth, Larissa Schaefer, Rhiannon Sowerbutts, Viktors Stebunovs, Joao Sousa, Garima Vasishta, and Julieta Yung for helpful comments, as well as participants at the Annual Meetings of the 2015 Southern Economic Association, 2016 CEBRA/WEAI, 2016 EMG-ECB Workshop on Global Liquidity and its International Implications, 3rd BIS-CGFS Workshop on research on global financial stability, IMF-Central Bank of Iceland conference on "Capital Flows, Systemic Risk, and Policy Responses," 2016 FIRS, 2017 SED, 2017 European Meeting of the Econometric Society, 2017 FMA Annual Meeting, the 2018 Emerging Markets Group Workshop on International Capital Flows at the City, University of London, the 2018 European Finance Association annual meeting, and seminar participants at the Bank of Canada, IMF, the Federal Reserve Board, and the Bank of Portugal. The authors thank Kelly Posenau for outstanding research assistance. The views stated herein are those of the authors and are not necessarily the views of the Federal Reserve Board, the Federal Reserve Bank of Boston, or the Federal Reserve System.
} 


\title{
Cross-Border Bank Flows and Monetary Policy
}

\begin{abstract}
We analyze the impact of monetary policy on bilateral cross-border bank flows using the BIS Locational Banking Statistics between 1995 and 2014. We find that monetary policy in the source countries is an important determinant of cross-border bank flows. In addition, we find evidence in favor of a cross-border bank portfolio channel. As relatively tighter monetary conditions in source countries erode the net worth and collateral values of domestic borrowers, banks reallocate their claims toward safer foreign counterparties. The cross-border reallocation of credit is more pronounced for banks in source countries with weaker financial sectors, which are likely to be more risk averse. Lastly, the reallocation is directed toward borrowers in safer countries, such as advanced economies or economies with an investment grade sovereign rating. By highlighting the effect of domestic monetary policy on foreign credit, this study enhances our understanding of the monetary policy transmission mechanism through global banks.
\end{abstract}

JEL classification: E52, F34, F36, G21

Keywords: bank lending, cross-border bank flows, monetary policy, portfolio rebalancing 


\section{Introduction}

In a domestic context, the transmission of monetary policy through domestic banks has received a great deal of attention in the literature (Kashyap and Stein, 2000; Jimenez et al., 2014a; Dell'Ariccia et al., 2017), but less is known about the cross-border transmission of monetary policy through global banks. The rapid expansion of cross-border bank flows over the past decades has made it critical to understand their role in the transmission of monetary policy 1 This paper fills a gap in the literature by highlighting the working of the portfolio channel in an international context. While existing empirical work has documented the cross-border implications of the bank lending channel (e.g., Cetorelli and Goldberg (2012), Morais et al. (2015)), there is less evidence on the rebalancing of banks' portfolios in a global context (e.g., Den Haan et al. (2007), Bruno and Shin (2015a)). This channel is of particular relevance, as assessing the determinants of the global composition of bank flows originated across countries may reveal new information about banks' global lending decisions and their implication for financial stability.

Changes in the stance of monetary policy affect bank lending through several channels. Under the bank lending channel, monetary tightening impacts the supply of credit through the banks' cost of funding (Bernanke and Gertler, 1995). As monetary tightening prompts banks to substitute reservable deposits with uninsured liabilities, banks encounter higher costs of funding and reduce their supply of bank loans (Kashyap et al. 1993) $)^{2}$ At the same time, the portfolio rebalancing channel predicts that changes in the stance of monetary policy prompt banks to rebalance loan portfolios, with monetary tightening causing reallocations toward relatively safer assets, either domestically or abroad. Thus, while the bank lending channel predicts changes in the total supply of credit, the portfolio channel predicts changes in the composition of credit in response to monetary policy actions. ${ }^{3}$ In a domestic context, Den Haan et al. (2007)

\footnotetext{
${ }^{1}$ The stock of global claims has increased from USD 10 trillion in 2000 to USD 27 trillion in 2016.

${ }^{2}$ Alternatively, banks with lower capital ratios may face a steeper external finance premium as monetary policy tightens, which leads to less credit origination Disyatat (2011).

${ }^{3}$ The balance sheet channel also affects banks' funding costs, as tighter monetary policy causes banks' net worth to deteriorate through changes in cash flows, net interest margins, and the valuation of assets through the discount factor (Bernanke and Gertler, 1995). Additionally, through the risk-taking channel, higher interest
} 
find that banks rebalance their portfolios toward relatively safer assets in order to safeguard their capital adequacy ratio in response to monetary tightening. We conjecture that a portfolio rebalancing channel is at work internationally as well. As monetary tightening deteriorates the net worth of domestic borrowers, global banks may reallocate lending to relatively safer borrowers abroad.

Within this framework, our paper examines how domestic monetary policy affects the domestic and cross-border supply of bank credit and the global composition of banks' credit portfolios. We address the following research questions: first, how does cross-border bank lending respond to changes in the relative stance of domestic monetary policy? Second, does cross-border bank lending respond differently than domestic bank lending to monetary policy changes? Third, to the extent that monetary policy prompts global banks to engage in an international rebalancing of their credit portfolio, what characteristics drive the reallocation of lending among recipient countries? In answering these questions, our paper benefits from the use of a novel dataset on cross-border banking flows between multiple source and recipient countries, which allows us to compare the responses of domestic and cross-border bank lending to changes in domestic monetary policy.

We hypothesize that, first, during episodes of domestic monetary tightening, global banks rebalance their portfolios by increasing lending to foreign borrowers that become relatively safer, consistent with the portfolio channel described earlier. Second, in response to domestic monetary tightening, we expect domestic lending to react differently than crossborder lending, as the former is more directly affected by higher policy rates through the bank lending channel. In contrast, we expect cross-border lending to be unaffected or to rise in response to tighter domestic monetary policy, to the extent that the portfolio channel offsets or even dominates the bank lending channel. Third, we conjecture that portfolio rebalancing will be more prevalent in countries of origin with weaker banking sectors, as their banks attempt to insulate themselves from monetary policy changes, and more prevalent toward borrowers in

rates may result in higher risk premiums because the perception of risk increases, which may be due to a traditional moral hazard or adverse selection mechanism. Paligorova and Santos (2017) and Jimenez et al. (2014b) provide empirical support of the risk-taking channel in the United States and Spain, respectively. 
safer recipient countries. Importantly, we attempt to document portfolio rebalancing driven by the shift in the perceived riskiness of domestic and foreign borrowers, rather than by the relative shift in domestic and foreign demand driven by investment opportunities or by currency appreciation caused by the domestic monetary tightening.

Our results are three-fold. First, domestic monetary tightening leads to an increase in cross-border lending. Specifically, a one-percentage point increase in the domestic monetary policy rate leads to about $8 \%$ higher cross-border bank flows. Across types of borrowers, the policy rate increase leads to about $4 \%$ higher flows to foreign banks and to $9 \%$ higher flows to foreign non-banks. In terms of magnitude, a percentage point increase in the domestic policy rate is associated with 0.33 percentage points higher quarterly growth of cross-border bank claims (0.37 percentage points for claims on foreign banks and 0.43 percentage points for claims on foreign non-banks), relative to an average growth rate of $4.11 \%$ for the total cross-border bank claims (9.04\% on foreign banks and $4.84 \%$ on foreign non-banks).

Second, pooling together the data on cross-border and domestic lending to non-bank borrowers, we find that global banks increase cross-border lending by more than domestic lending in response to domestic monetary tightening, as a decrease in domestic credit by smaller institutions may partially outweigh a positive effect on global banks that are insulated from changes in domestic policy rates (Cetorelli and Goldberg, 2012).

Third, we find evidence that banks'portfolio rebalancing is correlated with the crosssectional risk of lenders in source countries and with the risk of borrowers in destination countries. Although the dataset only provides a coarse decomposition of cross-border lending by loan type, the characteristics of source-recipient country pairs are indicative of the relative riskiness of domestic banks and foreign borrowers. Thus, domestic monetary tightening leads to stronger reallocations of credit away from source countries with weaker financial banking sectors. It also leads to stronger reallocations toward foreign borrowers in relatively safer destination economies, such as those with advanced economy or investment grade sovereign rating status. Overall, our results demonstrate that the standard domestic bank lending channel works together with a portfolio rebalancing channel in a cross-border context.

These findings contribute to our understanding of the global financial cycle and its im- 
plications for financial stability. As noted in the extant literature, aggregate banking flows fluctuate with movements in risk appetite, the broad dollar, and U.S. monetary policy MirandaAgrippino and Rey (2015); Avdjiev et al. (2017); Cerutti et al. (2017a); Rey (2016)). We find similar results for the determinants of overall cross-border bank flows, but we also provide new evidence suggesting that banks adjust their global portfolios by taking into account the relative stance of domestic monetary policy compared to that of foreign economies. Moreover, we find that banks tend to shift their portfolios towards safer borrowers as monetary policy tightens, especially if the domestic banking sector is in a relatively weaker position.

Another important contribution of our paper is the use of information on bilateral cross-border bank claims from the Locational Banking Statistics by residence (LBS) database compiled by the Bank for International Settlements (BIS). The data on bilateral bank claims allows us to compute cross-border bank flows at a quarterly frequency for the interval between 1995 and 2014, for a matrix of 29 reporting (source) countries and 77 counterparty (recipient) countries 4

The dyadic (i.e., bilateral) structure of our dataset allows us to overcome a number of challenges that are generally encountered in the empirical literature on international capital flows. First, to identify the effect of domestic monetary policy on the supply of cross-border bank flows, one challenge is to control for credit demand in the recipient countries. Otherwise, the supply-driven changes in cross-border lending attributed to monetary policy in source countries may be confounded with changes driven by credit demand in the recipient countries. The dyadic data provides a convenient way to separate the factors driving supply from those affecting demand by using counterparty*time fixed effects (with time given by year-quarter). The fixed effects control for unobserved time-variant factors that may affect the demand for credit in recipient countries. This strategy, which is similar in nature to that applied to firms by Khwaja and Mian (2008), relies on the existence of bank flows from multiple source countries lending to each recipient country in each year-quarter.

Second, in many studies on international capital flows, the balance of payments data

\footnotetext{
${ }^{4}$ We use the terms "reporting" and "source" country interchangeably, as countries that report t heir claims on foreign borrowers are the source countries. Similarly, "counterparties" are "recipient" countries.
} 
provides capital inflows for each recipient country, but without specifying the source countries. The dyadic nature of the BIS data allows us to break down bank inflows by source countries, and thus to examine the role of country-specific factors such as the stance of monetary policy in source countries, rather than focusing on global factors as the sole drivers of cross-border bank flows.

Third, empirical studies focus on either domestic bank lending or cross-border bank flows, but without jointly analyzing the two types of lending. As our research question addresses the international rebalancing of global banks' portfolios, comparing domestic with cross-border bank lending is necessary. We achieve this goal by combining the dyadic data on cross-border lending with data on bank credit to the domestic private non-bank sector (also from the BIS) and with data on bank credit to the domestic public sector (from national sources).

Our paper is related to an emerging stream of empirical literature that examines the role of global banks in the international transmission of monetary policy. Cetorelli and Goldberg (2012) show that U.S. global banks actively use fund transfers from foreign offices in response to monetary policy shocks in the United States. Brauning and Ivashina (2016) focus on the elevated hedging costs from currency mismatches between global banks funding and investment activities. Due to these hedging costs, global banks react to domestic monetary policy easing by increasing foreign reserves and decreasing lending in foreign markets. In addition, Morais et al. (2015) document an international risk-taking channel of monetary policy, where foreign monetary policy loosening is associated with increased supply of credit by foreign banks to Mexican firms, but their analysis does not explore cross-border flows. Instead, the focus of the paper is on the lending by subsidiaries of foreign banks in Mexico, whose links to the parents and home-country monetary policy may be limited, especially if they are part of a global bank operating a decentralized funding model (Bank for International Settlements, 2010). Finally, Bruno and Shin (2015b) argue that an appreciation of foreign currencies relative to the U.S. dollar strengthens the balance sheet of foreign borrowers and hence increases bank lending to foreign recipient countries. As with other studies that focus on the role of global factors in influencing cross-border bank flows (Cerutti et al., 2017a), data limitations force them to 
analyze the importance of these common factors or to focus on cross-sectional differences among borrowing countries. In contrast, our data allow us to understand the domestic and foreign operations of global banks, and to isolate the factors that determine the supply or demand for credit.

Our paper also adds to the existing empirical evidence on portfolio rebalancing, which focuses mostly in the domestic context. While abstracting from cross-border rebalancing, Den Haan et al. (2007) provides evidence that U.S. monetary tightening is followed by banks reallocating their portfolios away from loans deemed relatively risky, such as consumer and residential real estate loans, and toward loans deemed relatively safer, such as commercial and industrial loans. Similarly, other studies show that monetary loosening decreases risk aversion (Bekaert et al., 2013) and encourages the origination of riskier loans (e.g., (Paligorova and Santos, 2017; Dell'Ariccia et al., 2017)).

Our paper is also related to the empirical literature on the bank lending channel. Kashyap and Stein (2000) find that monetary policy tightening has an effect on lending by smaller banks, while its impact on larger banks is muted. Similarly, Cetorelli and Goldberg (2012) document that larger global banks are able to absorb changes in domestic monetary policy by using liquidity from their foreign offices, which also weakens the effect of the bank lending channel.

Finally, we add to the literature on the push and pull determinants of cross-border banking flows. While the existing literature defines push and pull factors along the lines of common and recipient country factors (Fratzscher, 2012), our dyadic data allow us to include country-specific factors from source countries among the push factors, such as the stance of domestic monetary policy, along with global factors. Besides documenting the role of monetary policy, we account for typical macroeconomic factors in source and recipient countries, such as GDP growth, inflation, indebtedness, credit growth, and bank equity returns. Our paper is also broadly related to a growing literature on the determinants of international capital flows, but which focuses on total or portfolio flows rather than on cross-border banking flows (Forbes and Warnock, 2012, Ahmed and Zlate, 2014; Ghosh et al., 2014).

The rest of the paper is structured as follows. Section 2 presents the data, and Section 3 
discusses the methodology. Section 4 documents the effects of monetary policy on cross-border bank flows, section 5 describes the main results on the role of monetary policy and portfolio rebalancing, section 6 presents additional robustness tests, and section 7 concludes.

\section{Data Sources and Summary Statistics}

\subsection{Data sources}

The main data source is the confidential LBS database by residence, compiled by the BIS and shared with the central banks of reporting countries. The LBS database contains quarterly data on the aggregate cross-border claims and liabilities of banks residing in 45 reporting countries to counterparties in roughly 200 countries (Bank for International Settlements, 2013). The first-difference of cross-border bank claims, which are already adjusted for exchange rate fluctuations across quarters by the BIS, gives the corresponding bank flows. We normalize flows by the lagged outstanding claims, thus obtaining a measure equivalent to the growth of claims. An advantage of the BIS data, compared to the banking flows collected from balance of payments statistics, is the detailed breakdown of the series by reporting and counterparty countries, hence the dyadic structure of the data. The claims and liabilities on counterparty countries are further detailed by currency, instrument (loan and debt securities), and type of counterparty (bank or non-bank) ${ }^{5}$

The LBS dataset includes observations dating back to 1977. However, some countries, especially emerging market economies, started reporting these data only from the early 2000s. This limitation, and the data constraints from other variables used in the empirical tests, reduced our sample to the period between 1995:Q1 and 2014:Q2 for 29 reporting countries and

\footnotetext{
${ }^{5}$ In the BIS definition, loans include all loans granted, working capital provided to branches/subsidiaries, and deposits with other banks, including those with their own affiliates (inter-office positions). This instrument category also includes repurchase transactions (repos), financial leases, promissory notes, non-negotiable debt securities (e.g. non-negotiable CDs), subordinated loans (including subordinated non-negotiable debt securities) and reporting banks' holdings of notes and coins that are in circulation. Debt securities are negotiable instruments other than loans and deposits, equity securities, investment fund shares or units, and financial derivatives. Non-banks include non-financial sectors (government sector, non-financial corporations, and households) and non-bank financial institutions (special purpose vehicles, hedge funds, securities brokers, money market funds, pension funds, insurance companies, financial leasing corporations, central clearing counterparties, unit trusts, other financial auxiliaries, development banks and export credit agencies).
} 
77 counterparty countries ${ }^{6}$ We also exclude from our sample the BIS reporting countries that serve as offshore centers, 7

The dyadic structure of the LBS data allows us to use various types of fixed effects to control for unobservable variation at the country level (see Section 3). Thus, the dyadic structure allows to disentangle changes in cross-border bank flows that are driven by supply factors specific to the reporting country from those arising from changes in the demand for credit from the counterparty country. Since multiple lending countries report claims on borrowers from the same counterparty country in one given quarter, the use of counterparty*time fixed effects serves to disentangle the effect of demand conditions from that of supply factors that vary across reporting countries. An additional advantage of the LBS dataset is that the cross-border claims denominated in multiple currencies are expressed in U.S. dollars and adjusted for exchange rate changes, which allows us to compute cross-border flows that abstract from exchange rate fluctuations over time 8

One drawback of the LBS dataset is that it does not contain the historical claims of domestic banks on borrowers residing in their home country, and hence does not allow computing banks' portfolio shares allotted to the domestic and foreign economies. Since some of our tests aim to assess whether banks substitute domestic for foreign claims, we overcome this limitation by constructing a new dataset of bank claims on the domestic non-bank sector (See Section 5). These domestic claims include both loans and debt securities, which is consistent with the composition of cross-border claims provided by the LBS. To construct the series of bank claims on the domestic non-bank sector, we use two sources of data: first, we use data on bank credit to the private non-financial sector, also provided by the BIS (Dembiermont et al. 2013). Second, we collect data on domestic banks' claims, loans and securities holdings, vis-

\footnotetext{
${ }^{6}$ Table A3 presents the list of countries included in the sample and the number of observations per country. France, Germany, Switzerland, and the United Kingdom have the largest number of observations as reporting countries, while the United Kingdom and the United States appear most frequently as counterparty countries.

${ }^{7}$ Offshore centers are typically used by corporations or banks to arrange financial transactions whose funds are redirected elsewhere for their final use (Avdjiev et al. (2014)). The pass-through nature of offshore centers makes their monetary policy irrelevant to the banking flows originated in these locations.

${ }^{8}$ Note that the currency compositions of cross-border claims are also reported, which allows the BIS to calculate the exchange rate-adjusted cross-border claims expressed in U.S. dollars for each reporting country. This is akin to a real measure of bank claims that strips out any currency variation.
} 
a-vis the public sector from national sources, which are consistent with the BIS methodology used to construct the cross-border claims. The resulting series are used to compute the growth in banks' domestic claims on non-banks, which are compatible with the measures described above.

We collect data on central banks' target or effective policy rates, our main explanatory variable of interest, directly from central banks or databases published by the International Monetary Fund. Some monetary authorities do not target specific rates, in which case we use the reference rate most widely used by market participants. For Eurozone countries, we use the individual countries' policy rates until the introduction of the euro, and the rate for Main Refinancing Operations (minimum bid rate) set by the European Central Bank for the rest of the sample period. For additional controls, we collect country-specific macroeconomic and financial variables such as GDP growth, inflation, debt/GDP, and bank equity returns from multiple sources including Datastream, Haver Analytics, and Bloomberg, all defined in Appendix 1.

\subsection{Summary statistics}

Table 1 presents a set of summary statistics for the cross-border bank flows computed as the growth in cross-border claims. We drop reporting-counterparty country pairs where the minimum outstanding claims in a given quarter are less than $\$ 5$ million or the total outstanding claims are negative. This growth in claims is expressed in percentage points and winsorized at the 2.5 percentile. As shown in the table, the growth in the quarterly cross-border claims visa-vis all sectors averages 4.1 percent during our sample period. By type of counterparties, the flows to banks averaged around 9 percent, while the cross-border flows to non-banks averaged 4.8 percent. The flows to banks were not only larger but also more dispersed than the flows to non-bank counterparties, as inferred by their standard deviations. In contrast to crossborder flows, the growth of domestic claims on non-banks was only 2.3 percent and had a lower standard deviation.

Table 1 also reports summary statistics for all variables used in the regressions grouped by both reporting and counterparty countries. Given that the sample of counterparty countries 
includes a higher number of emerging market economies relative to the sample of reporting countries, it is not surprising that the monetary policy and inflation rates are higher for the counterparty group, just like credit growth, bank equity returns, and real GDP growth.

Figure 1 plots the quarterly cross-border bank flows, in billions of dollars, of banks located in four regions: United States, Eurozone, other advanced economies, and emerging markets. We overlay these flows with the US effective federal funds rate, which is the target rate used by the Federal Open Market Committee (FOMC). US monetary policy has been suggested to be one of the drivers of the global financial cycle ( (Miranda-Agrippino and Rey, 2015)). There are a few relevant observations that can be extracted from this figure. First, as noted by several papers in the literature (e.g., Cerutti et al. (2017a), Avdjiev et al. (2017)), aggregate bank flows tend to move with the global financial cycle. Second, the composition of those flows is not uniformly distributed across the reporting regions as the global factors change. That is, the share of the supply of credit for each region varies across the financial cycle, a fact that seems more prevalent after the global financial crisis (GFS). The change in these shares are exactly the movements that we attempt to explain in our empirical analysis and what we call the portfolio channel. We test whether differences in the relative monetary policy stances across source countries affect the global composition of the supply of cross-border bank flows.

\section{Methodology}

This section outlines the empirical specifications used to test the relevance of the portfolio channel. We describe the main identification strategy to test for the effect of monetary policy on the composition of banks' portfolios across domestic and cross-border exposures.

\subsection{Specification for the role of monetary policy}

To estimate the effect of monetary policy in the reporting countries on cross-border bank flows, while controlling for the demand for credit in the counterparty countries, we rely on as set of panel regressions with fixed effects. In our first specification, we use a measure of quarterly 
cross-border flows as the dependent variable:

$$
\text { Flows }_{i j t} / \text { Outstanding }{ }_{i j-1}=\alpha \text { Policy rate } \operatorname{rep}_{i t-1}+\beta^{\prime} X r e p_{i t-1}+\gamma_{j t}+\epsilon_{i j t}
$$

where $i$ and $j$ indicate the reporting (source) and counterparty (recipient) countries, and $t$ denotes time at the quarterly frequency. We use three different measures of cross-border bank flows: first, the ratio between the change in total claims $\left(F l o w s_{i j t}\right)$ on all sectors in the counterparty country scaled by the lagged outstanding claims of the reporting country in a given quarter (Outstanding $\left.g_{i j-1}\right)$; second, we isolate the growth of claims on bank counterparties; and third, we focus on the growth of claims on non-bank counterparties. Thus, our analysis is focused not on the dollar amount of cross-border flows, but on the growth of cross-border claims, which is equivalent to the flows normalized by lagged claims.

The main regressor of interest in this specification is the lagged nominal monetary policy rate in the source country Lag policy rate repit-1.9 We use the level of the rate in this specification, as opposed to changes in the rate or estimated shocks, as we aim to capture the relative stance of monetary policy across countries at a given point in time (Bernanke and Mihov, 1998). Nominal rates are preferred to real rates when estimating the determinants of cross-border bank flows, because banks typically calculate their expected profits using nominal rates rather than real rates (Herrmann and Mihaljek, 2010). In addition, the selection of deflator in the context of cross-border monetary policy poses some challenges. Arguments can be made for using deflators either for the home or the host countries, depending on where the bank profits for the loan would be repatriated or reinvested in the host country, which is not observable. That said, we are aware that the degree of financial tightness associated with nominal rates also depends on the domestic rate of inflation, which motivates the inclusion of the inflation rate as an explanatory variable for reporting countries. Finally, because the reporting countries are typically large advanced economies, it is unlikely that credit demand in most of the counterparty countries used in our analysis directly affects monetary policy rates

\footnotetext{
${ }^{9}$ In section 4 we use shadow rates as an alternative measure of the monetary policy stance and LIBOR-OIS as a measure for bank funding costs.
} 
in reporting countries, which alleviates potential concerns arising from reverse causality.

As discussed in the introduction, we focus on the the portfolio rebalancing channel as the main motivation for our analysis. This channel predicts that in response to domestic monetary tightening banks reallocate their portfolios toward less risky assets, either domestically or abroad, in order to improve their net worth and strengthen their capital base. Therefore, a positive estimate for $\alpha$, the main coefficient of interest on the domestic monetary policy rate in source countries, would be consistent with cross-border portfolio rebalancing, whereby global banks shift their lending to safer foreign borrowers in response to a relatively tighter domestic monetary stance. In contrast, a negative coefficient would signal that monetary tightening effectively decreases banks' cross-border flows, like it does with domestic credit, which is consistent with the bank lending channel. The overall direction of the effect is uncertain, as both channels may operate in different directions, and even within each channel, some banking sectors, may react differently to monetary policy.

The empirical literature on banks' transmission of monetary policy has found that bank-specific characteristics affect the sensitivity of domestic and cross-border bank lending to the monetary policy stance. Larger, more liquid, and better capitalized banks are less affected by a tightening of monetary policy (Kashyap and Stein (2000) Cetorelli and Goldberg (2012)). These characteristics are associated with stronger balance sheets, a smaller degree of informational asymmetries, and hence, less variability in the external finance premium. For the same reason, we expect safer banks to be less engaged in portfolio rebalancing in response to monetary tightening owing to stronger balance sheets and lower funding costs (Den Haan et al. (2007)).

Cross-border bank flows are also affected by demand conditions in the recipient country. If monetary policy tightening in the reporting country overlaps with a credit boom abroad, an increase in cross-border flows could be associated with the increase in foreign credit demand and not to the tightening of monetary policy. To control for time-varying demand factors at the counterparty country level, we make use of the dyadic structure of our data and include counterparty*year-quarter fixed effects $\left(\gamma_{j t}\right)$. The identification of demand factors is driven by the variation in cross-border flows sent by different reporting countries to the same counter- 
party country in a given year-quarter. Therefore, our use of dyadic data achieves a cleaner identification of the impact of supply factors, including monetary policy, on cross-border flows compared with studies using balance-of-payment data.10

While the counterparty*year-quarter fixed effects control for demand conditions in the counterparty country, the monetary policy stance in the reporting country depends on domestic macroeconomic conditions that could also affect the cross-border flows. Therefore, omitted variable bias may affect the coefficient on the reporting country's policy rate as a driver of cross-border flows. We counteract this type of bias in two ways. First, we control for a set of macroeconomic variables in reporting countries that may affect the monetary policy rate either directly or indirectly, such as real GDP growth, inflation, and credit growth, which are included in $X r e p_{i t-1}$. Second, we use the Eurozone as a special case since the optimal monetary policy rates in some individual Eurozone members may have differed from those set for the Eurozone as a whole. For example, the economies of Eurozone member states have been at times unsynchronized and ECB policy actions may have been too loose for faster-growing member states such as Ireland, but too tight for slower-growing member states such as Italy ${ }^{11}$

We also include a set of reporting-country controls in $X r e p_{i t-1}$ that have been found to affect cross-border credit flows. A higher domestic debt-to-GDP ratio might be indicative of banks' lesser ability or willingness to expand lending abroad. We use country-level bank equity returns at the quarterly frequency to measure the health of the banking system and its viability to extend credit (Ghosh et al., 2014, Bruno and Shin, 2015a). We also include the quarterly change in exchange rates between country pairs, as appreciating counterparty currencies may encourage cross-border flows denominated in the reporting country's currency. Appreciating foreign currencies would enhance borrowers' balance sheets and their demand for

\footnotetext{
${ }^{10} \mathrm{~A}$ concern with this identification strategy may be that banks from different reporting countries face different borrowers in the same counterparty country, which would prevent us from controlling for the demand for crossborder flows using only fixed effects. However, as shown by Cerutti et al. (2015), an important fraction of cross-border claims on non-banks are intermediated through the global syndicated loan market. Borrowers on this market are likely to be more homogenous, as they have to satisfy minimum credit quality standards to be able to secure funds from global banks.

${ }^{11}$ The result is found in Lee and Crowley (2009), who conduct counterfactual exercises with a popular Taylor rule-type policy reaction function. Based on these exercises, the authors construct aggregate "stress" measures, which indicate the divergence of economic conditions within the euro area. Following Clarida et al. (1998), policy "stress" refers to the extent to which actual policy deviates from the optimal policy.
} 
credit (Kearns and Patel, 2016). We also control for the financial center status of reporting countries, namely, Hong Kong, Luxembourg, United Kingdom, United States, and Singapore. In addition, we consider whether the reporting country is part of the Eurozone, since some of these countries may be subject to common credit and business cycles, and hence may have similar credit supply conditions.

The monetary policy rate is an informative indicator of the monetary policy stance under normal circumstances. However, in our sample period, three central banks implemented unconventional monetary policy measures after their reference rate hit the effective lower bound, that is, Japan, the United Kingdom, and the United States 12 For these three countries, we construct an indicator variable equal to one for the duration of the quantitative easing program and zero otherwise.

The standard errors are double-clustered at the reporting and counterparty country levels, which is one of the most conservative clustering setups (Cameron and Miller, 2014). Clustering at the reporting country level accounts for the autocorrelation of the monetary policy rate and other macro variables over time, while clustering at the counterparty level accounts for the correlation of cross-border flows at the counterparty level.

\section{$3.2 \quad$ The portfolio channel}

The previous specifications allow us to test the relation between cross-border bank flows and monetary policy. However, to analyze the portfolio channel in detail, we explicitly examine banks' decision to adjust their portfolio of domestic and foreign credit, as monetary policy conditions change. To test for banks' portfolio reallocation, we use data on both domestic and cross-border credit to non-bank borrowers in the following specification:

$$
\text { Flows Differential }_{i j t}=\alpha \text { Policy rate } \operatorname{rep}_{i t-1}+\beta^{\prime} \text { Xrep }_{i t-1}+\gamma_{j t}+\epsilon_{i j t}
$$

Flows Differential ijt $_{\text {is the difference between } \text { Flows }_{i j t} / \text { Outstanding }}$ ijt-1 $_{\text {and Flows Domestic }}$

\footnotetext{
${ }^{12}$ ECB launched their public sector asset purchases program in 2015:Q1, which is outside the sample period of our paper.
} 


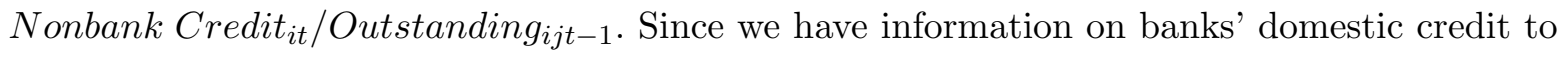
non-banks, we narrow the analysis to cross-border flows to non-banks as well ${ }^{13}$ If banks perform any portfolio rebalancing across domestic and foreign borrowers, $\alpha$ should be positive, since tighter monetary policy in reporting countries would be associated with faster growth of credit to foreign borrowers compared to domestic counterparties.

In a second set of tests, we examine whether the relationship between monetary policy and cross-border flows is stronger for banks that are more financially constrained. We expect that riskier reporting banking sectors (such as those with higher SRISK/GDP ratios, or banking sectors with lower ratings) will likely be more sensitive to monetary policy developments. As monetary policy tightens, banks that have weaker balance sheets should move away from riskier domestic assets into safer assets abroad. This would allow them to reduce the risk in their overall portfolio, as domestic financial conditions become more strained. Developed by Brownless and Engle (2017), SRISK is a suitable measure to capture the riskiness of a banking sector, because it estimates the amount of capital that a financial institution would need to raise in order to function normally under stress.

\subsection{Specification for robustness to global factors}

As noted previously, Miranda-Agrippino and Rey (2015) and Rey (2013) argue that crossborder flows are largely driven by a global factor, which in turn can be related to monetary policy in the center country, the United States. Also, Bruno and Shin (2015b) find that U.S. monetary policy is a key driver of cross-border bank flows, as local banks borrow in U.S. dollars from global banks, which in turn can access wholesale U.S. dollar financing in financial centers. To test for the robustness of monetary policy in the source country as a driver of cross-border banking flows, we rely on a regression similar to equation (1), but replacing the counterparty*year-quarter fixed effects with a separate set of fixed effects for reporting*counterparty pairs and for year-quarter. The latter captures the potential effect of

\footnotetext{
${ }^{13}$ Conceptually, it is also difficult to capture the effect of monetary policy on domestic credit within the banking sector, as on a residency basis, the assets for one set of banks are the liabilities for others. This, closed system, will be quite different to the network of global banking flows.
} 
a global factor. Alternatively, we use the VIX, instead of year-quarter fixed effects, to control for the effect of the global factor on cross-border bank flows, since the VIX is a proxy for the degree of risk appetite in asset markets (Bekaert et al., 2013).

$$
\begin{aligned}
& \text { Flows }_{i j t} / \text { Outstanding } \\
& i j t-1=\alpha \text { Policy rate } \operatorname{rep}_{i t-1}+\theta \text { Policy rate } \mathrm{cp}_{j t-1}+ \\
&=\beta^{\prime} X r e p_{i t-1}+\mu^{\prime} Y c p_{j t-1}+\gamma_{i j}+\phi_{t}+\epsilon_{i j t}
\end{aligned}
$$

This setup allows us to separately identify "push" factors from reporting countries Xrep it-1 and "pull" factors from counterparty countries $\left(Y c p_{j t-1}\right)$, while also controlling for a timevariant global factor. ${ }^{14}$ We include the same set of counterparty controls, $Y c p_{j t-1}$, as for the reporting countries (Ahmed and Zlate, 2014, Ahmed et al., 2015). The year-quarter fixed effect, $\phi_{t}$, controls for the unspecified global factor, while the reporting-counterparty pair fixed effect $\gamma_{i j}$ controls for unobserved factors at the pair level that may drive the cross-border flows. With this specification we are able to assess whether monetary policy in the source country is a relevant driver when controlling for a global factor. Our conjecture is that, if the global factor were the driver of both banking flows and monetary policy in the source countries, the effect of monetary policy would vanish when the global factor is taken into account. On the contrary, if monetary policy still has a role when accounting for the global factor, the results from our baseline specification should hold.

\section{Cross-border credit and monetary policy}

Table 2 presents estimates testing the relationship between monetary policy in reporting countries and cross-border bank flows. These estimations are based on specification (1). In column (1), the dependent variable is the growth of cross-border claims to all sectors of recipient countries (bank, non-bank, and unallocated sectors). The coefficient on Policy rate rep shows that a one percentage point increase in the monetary policy rate in a source country is associated with 0.33 percentage point increase in cross-border flows. Given that bank flows are 4 percent

\footnotetext{
${ }^{14}$ Calvo et al. (1996) emphasize the importance of external push factors in explaining capital flows to emerging economies in the 1990s.
} 
of claims on average, this impact is economically significant, as it implies about 8 percent larger flows. In addition, in columns (2) and (3), we split the cross-border flows into those to bank and non-bank foreign borrowers, respectively. We find that a one-percentage point increase in the monetary policy rate in the source country leads to a 0.37 percentage point increase in credit to banks and 0.43 percentage point increase in credit to non-bank counterparties. Once again, the impact is economically significant, as it represents 4 and 9 percent larger flows respectively. These results are robust to excluding the United States and other financial centers from the sample. Further, since we rely on counterparty*year-quarter fixed effects to control for changes in credit demand, these estimates are relevant for the cross-section of reporting countries that have a common counterparty in a given year-quarter.

Our finding showing a positive relation between a relatively tighter monetary policy stance and larger cross-border flows is not necessarily inconsistent with the bank lending channel. As noted before, under that channel we would expect a tightening in monetary policy to lead to a decrease in total bank credit, comprising both domestic and foreign destinations. However, banks' international exposures through cross-border lending represent only a fraction, albeit important for some countries, of banks' overall balance sheets. The bank lending channel would still be operative if the contraction in domestic credit outweighs the increase in cross-border credit. Moreover, some of the banks that participate in cross-border lending activities are those identified by Kashyap and Stein (2000) as being less sensitive to domestic monetary policy. In contrast, smaller banks, which focus on domestic credit orignation may be more sensitive to the domestic monetary policy stance, affecting their domestic lending. The trade-off between domestic and cross-border credit is presented in the next section.

Turning back to the results in Table 2, we find that among the reporting-country controls higher government debt-to-GDP is associated with lower cross-border flows. In addition, positive changes in a reporting country's nominal exchange rate (i.e., reflecting an appreciation of the counterparty's currency) are associated with more cross-border bank flows. Interestingly, financial centers lend less abroad compared with other countries, consistent with a view that these countries are larger capital recipients than senders. The Eurozone countries also produce less cross-border bank flows, on average, than the rest of the world. Interestingly, the $Q E$ 
indicator rep has a positive and statistically significant coefficient for total cross-border flows, meaning that cross-border bank credit grew at a faster pace during the quantitative easing period. This finding is not statistically significant when the flows are detailed by bank and non-bank borrowers.

Next, we present a series of robustness checks. First, given the new environment faced by banks since the GFC with elevated global uncertainty, the use of unconventional monetary policy, and new regulatory requirements for banks, we check whether the results reported above are preserved when the pre- and post-crisis periods are considered separately. In Table 3. columns (1)-(3) show results for the period before 2007:Q2. The coefficient on the monetary policy rate is positive and statistically significant for all three types of cross-border bank flows. In columns (4)-(6), which cover the period after 2007:Q2, the positive and statistically significant effect is preserved for the cross-border credit to all sectors in column (4), although not for the flows to banks and non-bank counterparties taken separately. Interestingly, the negative effect of government debt-to-GDP ratio on cross-border flows is present only for the period after 2007:Q2, when sovereign risk increased for several reporting countries. Also, Eurozone countries had lower cross-border flows than the rest of the sample after 2007:Q2, which is not surprising given the sovereign debt crisis and its effects on banks in the region.

The second set of robustness tests focuses on the role of banks' funding costs and alternative measures of monetary policy on cross-border credit. We use the LIBOR-OIS spread as a proxy for banks' cost of funding 15 In Table 4 , we add the lagged LIBOR-OIS spread to the explanatory variables used in Table 2, and repeat the estimation for the full sample (columns 1-3) and the post-2007:Q2 period taken separately (columns 4-6). The effect of monetary policy on cross-border flows is statistically significant and still positive after controlling for the LIBOR-OIS spread, with the exception of columns (2) and (5), which show results for crossborder flows to banks. The LIBOR-OIS spread has a negative and statistically significant effect on the cross-border flows to non-banks, suggesting that higher funding costs for banks lead

\footnotetext{
${ }^{15}$ (Giannetti and Laeven 2012) use LIBOR-OIS spread as a proxy for bank funding costs to study how funding conditions in the countries of origin of international banks affect the relative amount of domestic and foreign syndicated loans originated by these banks.
} 
to less cross-border lending (columns 3 and 6). The significance of the LIBOR-OIS spread is driven by the crisis and post-GFC period as the results for the pre-GFC period (not shown) are not significant. The LIBOR-OIS spread appears to capture financing stress in interbank markets (Correa et al. 2015), but funding cost are driven by monetary policy in normal times.

With monetary policy rates having persisted near the effective lower bound in the postcrisis period, we use a shadow interest rate based on a two-factor model of sovereign yields (Krippner, 2013) as an alternative measure of monetary policy. This measure allows us to capture the stance of monetary policy at the effective lower bound for the Eurozone, Japan, the United Kingdom, and the United States. As shown in columns (7)-(9) of Table 4, the relationship between the shadow interest rates in reporting countries and cross-border bank flows remains positive and statistically significant. This finding provides additional evidence that our results on the effect of monetary policy on cross-border bank flows are robust to episodes when unconventional monetary policy is used.

Overall, the relation between the relative stance of monetary policy across countries and cross-border bank flows is positive and significant, even when using alternative monetary policy measures and proxies for banks' funding costs. Banking sectors increase their crossborder claims as domestic monetary conditions become relatively tighter.

\section{The portfolio channel}

The previous section discussed the effect of monetary policy on cross-border bank flows. In this section, we focus on the differentiated responses of domestic and cross-border lending to changes in domestic monetary policy, in order to better understand the interplay between the bank lending and portfolio rebalancing channels. Specifically, we examine whether domestic lending is relatively less responsive than foreign credit to domestic monetary tightening, and whether the cross-sectional reallocation of cross-border credit is correlated with characteristics of source and destination economies. Thus, we ask whether cross-border credit is reallocated away from source countries with riskier banking sectors and towards safer destinations in response to a relatively tighter monetary policy stance in the source country. 


\subsection{Do banks substitute domestic for foreign credit?}

To analyze the global allocation of banks' credit portfolios, we merge information on crossborder claims with that of domestic claims on non-bank borrowers. With these data, we estimate specification (2), which allows us to examine whether the growth of cross-border bank claims is affected differently than that of domestic claims, when monetary policy changes in reporting countries. Table 5 presents the results.

In the specification reported in column (1), we stack data on cross-border bank flows with that on domestic credit for each reporting country. Thus, for banks aggregated by each reporting country, we have separate entries for their claims on foreign and domestic non-bank borrowers. This setup still allows us to control for the domestic credit demand, as common changes in the claims of all reporting countries on domestic residents are captured by the counterparty*year-quarter fixed effects.

To capture the differential effect of the monetary policy stance on cross-border and domestic credit, we interact Lag policy rate rep with a Domestic Indicator that takes the value one for domestic lending (from the domestic banking sector to domestic non-bank residents) and zero for cross-border lending. The positive sign on Lag policy rate rep suggests that cross-border claims on non-banks increase as monetary policy is relatively tighter. However, the negative coefficient on the interaction term between the monetary policy proxy and the domestic indicator suggests that domestic and cross-border lending respond differently to domestic monetary tightening, with the latter being significantly less sensitive.

We also estimate a more restrictive model in column (2), whereby the dependent variable is defined as the difference between the cross-border and domestic credit growth rate. The positive and statistically significant estimate suggests that the differential between cross-border and domestic credit growth increases as monetary policy in the reporting country becomes tighter, which is consistent with the findings in column (1). 


\subsection{Cross-border credit and monetary policy in riskier banking sectors}

We determined in the previous section that banks rebalance their credit portfolio towards foreign borrowers as monetary policy tightens. If these actions are driven by the need to insulate banks' balance sheets from the risks posed by tighter domestic monetary conditions, we should find a larger sensitivity to monetary policy for banking sectors that are more capital constrained. We proceed to test this hypothesis in this section.

We use Brownless and Engle (2017)'s SRISK measure as a proxy for the health of banking sectors in our tests. It is an estimate of the amount of capital that a financial institution would need to raise to function normally in the event of a large financial shock. Banks can reduce their SRISK by decreasing their size, leverage, or risk. To account for the heterogenous size of banking sectors in our sample, we scale the measure by the GDP of reporting countries, and construct an indicator variable $H$ RISK that takes the value of one for values of SRISK higher than the median values and zero otherwise.

In the results shown in column (3) of Table 5, we include the indicator variable $H$ RISK and an interaction between this term and the Lag policy rate rep 16 The positive estimate on this interaction term confirms that banking sectors with higher SRISK rebalance their portfolios more toward foreign borrowers in response to monetary tightening. This may be an attempt to insulate themselves from the potential turning of the domestic business cycle. We also find that riskier banking sectors, in general, have higher domestic, rather than crossborder, credit growth rates. This shown by the coefficient on $H$ RISK, which is negative and statistically significant.

Similarly, banks in countries with larger mortgage markets may be more prone to tilt their portfolios towards cross-border claims, as monetary policy becomes relatively tighter. As noted by (Den Haan et al., 2007), US banks tend to shift their portfolios from mortgages towards commercial and industrial (CI) loans as monetary policy tightens. The longer duration on mortgages and, in some cases, their fixed rate structure makes a shift towards CI loans more attractive during a rising rate environment, as CI loans have typically shorter durations and

\footnotetext{
${ }^{16}$ The number of observations in column (3) drops due to the data availability for SRISK.
} 
have floating rates. We use this premise to test whether banks hedge their exposures to interest rate risk by increasing their cross-border exposures. Note that cross-border claims are typically floating rate and about a third are syndicated lending arrangements (Cerutti et al., 2015).

In column (4), we interact the domestic monetary policy variable with the share of housing credit in total credit for each reporting country. The coefficient estimate is positive and statistically significant, suggesting that banks rebalance away from countries with more exposure to long-term assets such as residential mortgage loans. The result is in line with the findings in (Den Haan et al., 2007), where banks rebalance away from real estate loans and into CI loans.

Finally, we use information from (Cerutti et al., 2017b) to classify reporting countries' housing markets according to the most prevalent type of mortgage arrangement. We construct an indicator variable equal to one if the most prevalent mortgages are fixed rate or a mix between floating and fixed, and zero otherwise. As noted before, we expect that banks in countries with more prevalent fixed rates will shift their portfolios towards cross-border credit. Consistent with this hypothesis, the results in column (5) suggest that banks indeed rebalance their portfolios in countries where fixed-rate residential mortgages are more prevalent when monetary becomes relatively tighter.

Overall, the results are consistent with our hypothesis that banks use their international exposures to adapt their balance sheets to changes in macroeconomic risk. This will only be true, if banks indeed rebalance their portfolios towards safer countries or borrowers, which is the subject of the next section.

\subsection{Is cross-border credit reallocated to safer counterparties?}

The portfolio rebalancing channel suggests that cross-border bank flows should be directed toward relatively safer borrowers when monetary policy tightens in the reporting country. To test whether the relationship between cross-border credit and monetary policy depends on counterparty risk, we conduct two tests. The first test focuses on assessing the degree of rebalancing toward investment and speculative-grade countries, and the second one on the shift between advanced and emerging economies. We expect that banking sectors would adjust 
their portfolios towards investment grade and advanced countries as monetary policy becomes relatively tighter.

In the first set of tests, we interact the reporting-country policy rate with an indicator variable labeled Speculative grade $c p$, which takes the value of one if the counterparty country has a speculative-grade rating in a given year-quarter, and zero otherwise. As shown in Table 6, the coefficient on the monetary policy rate is still positive and statistically significant when including the interaction term. However, the negative coefficient on the interaction term indicates that cross-border credit to speculative-grade countries decreases as domestic monetary policy tightens. The overall effect of monetary policy on cross-border flows to speculative grade countries is captured by the sum of Lag policy rate rep and Lag policy rate rep $\times$ Speculative grade $c p$, reported at the bottom of the table. This sum is not statistically significant for all flows (column 1) and for flows toward bank borrowers (column 2). This result shows that in response to relatively tighter monetary policy at home, cross-border bank flows increase only to banks in investment-grade counterparty countries, which is consistent with portfolio rebalancing. In contrast, cross-border bank flows increase to non-bank borrowers in both investment and speculative-grade counterparty countries (column 3). One potential explanation for this result is that cross-border credit to non-banks typically takes the form of syndicated loans to large multinational corporations, whose credit ratings are high and hence less sensitive to local economic conditions.

As an alternative measure of counterparty country risk, we use information on whether a country is classified as an advanced economy or an emerging market. In Table 7 we report the results from the interaction of $E M E c p$ with each variable in the cross-border bank flows regression. Our coefficients of interest are Lag policy rate rep and Lag policy rate rep $\times$ EME cp. The positive and significant coefficient on the monetary policy measure and the negative sign on the interaction term with the EME indicator variable (except for non-bank borrowers), corroborates the findings from the previous table that cross-border credit is reallocated to borrowers in safer counterparty countries when monetary policy in the reporting country becomes relatively tighter. Also in line with the previous results, cross-border bank flows increase to non-bank borrowers regardless of their location in an advanced or emerging economy. 
Overall, these findings are consistent with our portfolio channel hypothesis, in which cross-border bank credit flows towards safer borrowers when monetary policy in the domestic country tightens.

\section{Additional robustness checks}

In this section, we conduct additional tests to determine whether the relation between monetary policy and cross-border bank claims is robust to different measures and specifications. We also assess the role of global factors and U.S. dollar funding conditions on cross-border bank flows.

\subsection{Economic conditions in the reporting countries}

A concern is that our analysis could be subject to the endogeneity of monetary policy to economic activity in the reporting country as they evolve simultaneously. Hence, cross-border bank flows may be driven by economic conditions rather than monetary policy in reporting countries. In an attempt to isolate the effect of monetary policy from that of domestic economic conditions, we use the Eurozone as an empirical setup in which monetary policy may become misaligned with domestic economic conditions. Under the assumption that Eurozone monetary policy may not co-move strongly with macroeconomic conditions in certain member countries (e.g., in relatively smaller countries like Ireland or Spain), the relationship between monetary policy and cross-border bank claims is expected to be properly identified. However, if the estimate on monetary policy is insignificant for those Eurozone reporting countries whose monetary policy and economic conditions are presumably not aligned, our main specification could be poorly identified due to the endogeneity of monetary policy. In particular, we test whether the relationship between cross-border bank flows and monetary policy differs between the Eurozone and non-Eurozone reporting countries.

In Table 8, we interact Euro rep, an indicator variable equal to one for Eurozone countries, with the main regressors and control variables in our specification. Our focus is on the interaction term, Policy rate rep $\times$ Euro rep. The results for this test are reported in columns (1)-(3). The coefficient on the monetary policy rate is positive and significant across all 
specifications, and its magnitude is larger for the Eurozone than for the non-Eurozone reporting countries, as shown by the sum of coefficients at the bottom of the table (the t-statistics is displayed in parenthesis).

Since monetary policy decisions in the Eurozone could be more synchronized with French and German economic conditions, we conduct a stricter experiment by excluding France and Germany from the estimating sample of reporting countries. The results presented in columns (4)-(6) show that the estimates on the interaction term (Policy rate rep $\times$ Euro rep) are even stronger than for the full set of Eurozone countries, suggesting that monetary policy has an independent effect on cross-border bank credit that is independent from the endogenous component of monetary policy driven by domestic economic conditions.

In a second set of tests, we also examine whether the relationship between monetary policy and cross-border bank lending is strongly correlated with economic conditions in the reporting countries. Figure A2.1, in the appendix, shows that the policy rate is similarly distributed across high- and low-GDP growth regimes, suggesting that the effect of monetary policy may be independent from that of domestic economic conditions in our sample. In Table 9. we formally test whether the results for high- and low-growth countries differ, shedding some additional light on whether our identification suffers from endogeneity problems. The coefficient on the interaction term between Policy rate rep and HGDP rep (an indicator variable that takes one if the quarterly GDP growth is higher than the sample median in a given period) is relatively small in magnitude and is not statistically significant for any of the dependent variables, suggesting that the effect of monetary policy is independent from that of the GDP growth in the reporting country.

Lastly, in Table 10, we report results from a similar exercise, where we compare the relation between monetary policy and cross-border bank flows for periods with currency appreciation and depreciation in reporting countries. With this test we attempt to address potential concerns that cross-border bank flows may be driven by exchange rate movements rather than monetary policy (Kearns and Patel, 2016). The lack of statistical significance on the interaction term between the indicator variable Appr (an indicator variable that takes one if the counterparty currency appreciates in a given quarter) and the monetary policy rate confirms 
that the relationship between monetary policy and cross-border bank flows is independent from domestic exchange rate conditions. This finding is further reinforced by the comparable distributions of monetary policy and currency regimes shown in Figure A2.2, also in the appendix.

Overall, using three different tests, we find that the effect of monetary policy on crossborder bank flows is not likely driven by economic conditions in reporting countries.

\subsection{Global factors}

As noted previously, an extensive literature has described the importance of global factors in influencing capital flows (Avdjiev et al., 2017). Our main specifications include ountrerparty*yearquarter fixed effects, which capture the effect of any global factors on cross-border bank flows. However, we follow two paths to further assess the importance of relative domestic monetary policy conditions, beyond the effect of global factors, on cross-border bank flows. These specifications nest our results within those proposed in the global factors studies. First, we use reporting-countrerparty pair fixed effects and year-quarter fixed effects, along with monetary policy rates in the source and recipient countries, instead of countrerparty*year-quarter fixed effects in our specifications. The year-quarter fixed effects should control for any unobserved global factors. Second, using fixed effects for reporting*counterparty pairs and year fixed effects, we include the VIX among the explanatory variables, since this variable has been found to proxy for global liquidity and financial conditions (Miranda-Agrippino and Rey, 2015) 17

In Table 11, columns (1)-(3), we estimate specification (3) with reporting-counterparty and year-quarter fixed effects. Taking into account time-invariant effects within the reportingcounterparty country pairs, the additional year-quarter fixed effects control for the quarterly global factor. In column (1), the coefficient on the policy rate in reporting countries is positive and statistically significant, while the coefficient on the counterparty countries' policy rate is negative and statistically significant, suggesting that cross-border credit flows to countries with lower monetary policy rates. This finding corroborates the argument that banks avoid

\footnotetext{
${ }^{17}$ Instead of year-quarter, we use year fixed effects in order to estimate the impact of VIX.
} 
lending to relatively riskier borrowers at home in favor of less risky borrowers in counterparty countries where collateral values and net worth are higher (i.e., due to lower policy rates). Similar conclusions arise from the results in columns (2) and (3) for cross-border bank flows to banks and non-banks, respectively.

In terms of other control variables, Lag credit growth $c p$ is positive and significant, implying that the demand for credit from the counterparty country attracts capital flows to all sectors. The same holds when the counterparty country has high GDP growth, while a high sovereign debt-to-GDP ratio deters cross-border credit. In the reporting country, high sovereign debt is also a barrier to cross-border credit, likely because the sovereign is relatively strained affecting banks' ability to venture to foreign markets. Finally, during the QE episodes, when banks' liquidity is elevated, cross-border flows are higher compared with other periods without QE policies. It is likely that QE policy allows banks to expand their balance sheet and hence their cross-border credit.

In columns (4)-(6) we include the VIX, which captures investors' perception of global risk and risk aversion (Bekaert et al., 2013). While the VIX affects cross-border flows negatively, consistent with the existing literature, the monetary policy rate in the reporting country still has a positive impact on cross-border bank flows, while the policy rate in the counterparty countries has a negative impact on cross-border flows. Lastly, in columns (7)-(9), monetary policy is measured by the policy rate differential between the reporting and counterparty countries. The positive coefficient on the monetary policy differential is preserved.

These findings show that the impact of domestic monetary policy on cross-border bank flows is important even after controlling for the role of global factors measured by the VIX. In this regard, policy makers still have levers to affect the international exposures of domestic banks, even if global factors are an important source in the variation of cross-border bank flows.

\subsection{U.S. dollar funding}

To the extent that global banks use dollar-denominated liabilities to finance cross-border claims, it may be the case that U.S. monetary policy, rather than the monetary policies of 
reporting countries, is the sole driver of cross-border bank flows globally. We address this concern using a new set of tests that takes into account the degree of dollar cross-border bank funding of reporting countries. In the specifications presented in Table 12 , we enhance our standard estimating equation with the ratio of banks' dollar-denominated cross-border liabilities over cross-border claims (USD CB Liabilities/CB Claims rep) for each reporting country. This ratio captures the share of cross-border claims that are potentially funded with cross-border liabilities denominated in dollars. We then interact this ratio with the U.S. policy rates. For these tests, we omit the United States as a reporting country from the sample.

If cross-border flows are driven solely by U.S. monetary policy rates rather than the source countries' monetary policy rate, we would expect the coefficient estimate on the latter to lose statistical significance. As shown in Table 12, we find that the coefficient of the reportingcountry monetary policy rate is still positive and statistically significant, which suggests that our results are not driven by the U.S. monetary policy stance and global banks' dollar funding. The interaction term between the degree of dollar cross-border funding and the U.S. policy rate is negative but not statistically significant.

In sum, the reporting-country monetary policy rate acts as and independent factor in determining the growth of cross-border bank flows across countries, even after controlling for the potential influence of the U.S. monetary policy stance.

\section{Conclusion}

The rapid expansion of cross-border bank flows over the past three decades have made it critical to understand the main drivers of these international transactions. Our paper focuses on the role of global banks in the cross-border transmission of monetary policy.

We use information from the BIS Locational banking statistics, as well as a novel dataset with information on banks' claims on the domestic non-bank sector. The dyadic structure of these data allows us to control for factors affecting the demand for cross-border bank flows, which helps to identify the effect of domestic monetary policy on the supply of cross-border credit. 
Our paper provides three main results. First, a relatively tight monetary policy in source countries is associated with portfolio rebalancing whereby cross-border claims grow more relative to domestic credit. Second, banks appear to rebalance their portfolios toward foreign non-bank borrowers, especially when they reside in source countries with relatively weaker financial sectors. Third, banks reallocate credit mainly toward foreign borrowers in safer economies, such as advanced economies or economies with investment grade ratings.

Our results have a number of policy implications. To the extent that an economy relies on foreign credit, policy makers should pay attention to monetary policy developments in source countries. Similarly, for home countries, policy makers should be aware that monetary policy decisions may lead to a change in banks' global credit portfolios. Our paper leads to a number of interesting research questions such as whether recipient countries will impose barriers to cross-border flows during upturns when additional credit may not be desirable; whether unconventional monetary policy leads to cross-border portfolio adjustments; and whether portfolio adjustments occur for different bank assets. 


\section{References}

Ahmed, S., Curcuru, S., Warnock, F., and Zlate, A. (2015). The two components of international capital flows. Boston Federal Reserve.

Ahmed, S. and Zlate, A. (2014). Capital flows to emerging market economies: A brave new world? Journal of International Money and Finance, 48:221-248.

Avdjiev, S., Chui, M., and Shin, H. (2014). Non-financial corporations from emerging market economies and capital flows. BIS Quarterly Review, December.

Avdjiev, S., Gambacorta, L., Goldberg, L. S., and Schiaffi, S. (2017). The shifting drivers of global liquidity. Staff Reports 819, Federal Reserve Bank of New York.

Bank for International Settlements (2010). Funding patterns and liquidity management of internationally active banks. Number 39 in CGFS Papers. Bank for International Settlements.

Bank for International Settlements (2013). Guidelines for reporting the BIS international banking statistics. Technical report, Bank for International Settlements.

Bekaert, G., Hoerova, M., and lo Duca, M. (2013). Risk, uncertainty and monetary policy. Journal of Monetary Economics, 60:771-788.

Bernanke, B. and Gertler, M. (1995). Inside the black box: The credit channel of monetary policy transmission. Journal of Economic Perspectives, 9:27-48.

Bernanke, B. S. and Mihov, I. (1998). Measuring monetary policy. The Quarterly Journal of Economics, 113(3):869-902.

Brauning, F. and Ivashina, V. (2016). Monetary policy and global banking. Mimeo.

Brownless, C. and Engle, R. (2017). SRISK: A conditonal capital shortfall measure of systemic risk. Review of Financial Studies, 30:48-79.

Bruno, V. and Shin, H. (2015a). Capital flows and the risk-taking channel of monetary policy. Journal of Monetary Economics, 71:119-132. 
Bruno, V. and Shin, H. (2015b). Cross-border banking and global liquidity. Review of Economic Studies, 82:535-564.

Calvo, G., Leiderman, L., and Reinhart, C. (1996). Capital flows to developing countries in the 1990s: Causes and effects. Journal of Economic Perspectives, 10:123-139.

Cameron, A. C. and Miller, D. L. (2014). Robust inference for dyadic data. Unpublished manuscript.

Cerutti, E., Claessens, S., and Ratnovski, L. (2017a). Global liquidity and cross-border bank flows. Economic Policy, 32(89):81-125.

Cerutti, E., Dagher, J., and Dell'Ariccia, G. (2017b). Housing finance and real-estate booms: A cross-country perspective. Journal of Housing Economics, 38(C):1-13.

Cerutti, E., Hale, G., and Minoiu, C. (2015). Financial crises and the composition of crossborder lending. Journal of International Money and Finance, 52:60-81.

Cetorelli, N. and Goldberg, L. (2012). Banking globalization and monetary transmission. Journal of Finance, 5:1811-1843.

Clarida, R., Gali, J., and Gertler, M. (1998). Monetary policy rules in practice: Some international evidence. European Economic Review, 42:1033-1067.

Correa, R., Goldberg, L., and Rice, T. (2015). International banking and liquidity risk transmission: Evidence from the United States. IMF Economic Review, 63(3):626-643.

Dell'Ariccia, G., Laeven, L., and Suarez, G. A. (2017). Bank leverage and monetary policy's risk-taking channel: Evidence from the united states. The Journal of Finance, 72(2):613654.

Dembiermont, C., Drehmann, M., and Mukakunratana, S. (2013). How much does the private sector really borrow a new database for total credit to the private non-financial sector. $B I S$ Quarterly Review, March. 
Den Haan, W., Sumner, S., and Yamashiro, G. (2007). Bank loan portfolios and the monetary transmission mechanism. Journal of Monetary Economics, pages 904-924.

Disyatat, P. (2011). The bank lending channel revisited. Journal of Money, Credit and Banking, $43(4): 711-734$.

Forbes, K. and Warnock, F. (2012). Capital flow waves: Surges, stops, flight, and retrenchment. Journal of Internaltional Economics, 88:235-251.

Fratzscher, M. (2012). Capital flows, push versus pull factors and the global financial crisis. Journal of International Economics, 88(2):341-356.

Ghosh, A., Quareshi, M., Kim, J., and Zeldueno, J. (2014). Surges. Journal of International Economics, 92:266-285.

Giannetti, M. and Laeven, L. (2012). Flight home, flight abroad, and international credit cycles. The American Economic Review, 102(3):219-224.

Herrmann, S. and Mihaljek, D. (2010). The determinants of cross-border bank flows to emerging markets: new empirical evidence on the spread of financial crisis. BIS Working Papers, 315 .

Jimenez, G., Ongena, S., Peydro, J., and Saurina, J. (2014a). Hazardous times for monetary policy: What do 23 million loans say about the impact of monetary policy on credit risktaking? Econometrica, 82 (2):463-505.

Jimenez, G., Saurina, J., Ongena, S., and Peydro, J. (2014b). Hazardous times for monetary policy: What do twenty-three million bank loans say about the effects of monetary policy on credit risk-taking? Econometrica, 82:463-505.

Kashyap, A., Stein, J., and Wilcox, D. (1993). Monetary policy and credit conditions: Evidence from the composition of external finance. American Economic Review, 83 (1):78-98.

Kashyap, A. K. and Stein, J. (2000). What do a million observations on banks say about the transmission of monetary policy? American Economic Review, 90:407-428. 
Kearns, J. and Patel, N. (2016). Does the financial channel of exchange rates offset the trade channel? BIS Quarterly Review.

Khwaja, A. I. and Mian, A. (2008). Tracing the impact of bank liquidity shocks: Evidence from an emerging market. American Economic Review, 98 (4):1413-1442.

Krippner, L. (2013). Measuring the stance of monetary policy in zero lower bound environments. Economics Letters, 118 (1):135138.

Lee, J. and Crowley, P. (2009). Evaluating the stresses from ECB monetary policy euro area. Bank of Finland Research, Discussion Paper 11.

Miranda-Agrippino, S. and Rey, H. (2015). World Asset Markets and the Global Financial Cycle. NBER Working Papers 21722, National Bureau of Economic Research, Inc.

Morais, B., Peydro, J.-L., and Ruiz Ortega, C. (2015). The international bank lending channel of monetary policy rates and QE: Credit supply, reach-for-yield, and real effects. International Finance Discussion Papers 1137, Board of Governors of the Federal Reserve System (U.S.).

Paligorova, T. and Santos, J. (2017). Monetary policy and bank risk-taking: Evidence from the corporate loan market. Journal of Financial Intermediation, 30:35-49.

Rey, H. (2013). Dilemma not trilemma: The global financial cycle and monetary policy independence. Proceedings of the Federal Reserve Bank of Kansas City Economic Symposium at Jackson Hole.

Rey, H. (2016). International Channels of Transmission of Monetary Policy and the Mundellian Trilemma. IMF Economic Review, 64(1):6-35. 
Figure 1: Composition of Cross-Border Bank Flows and the U.S. Policy Rate

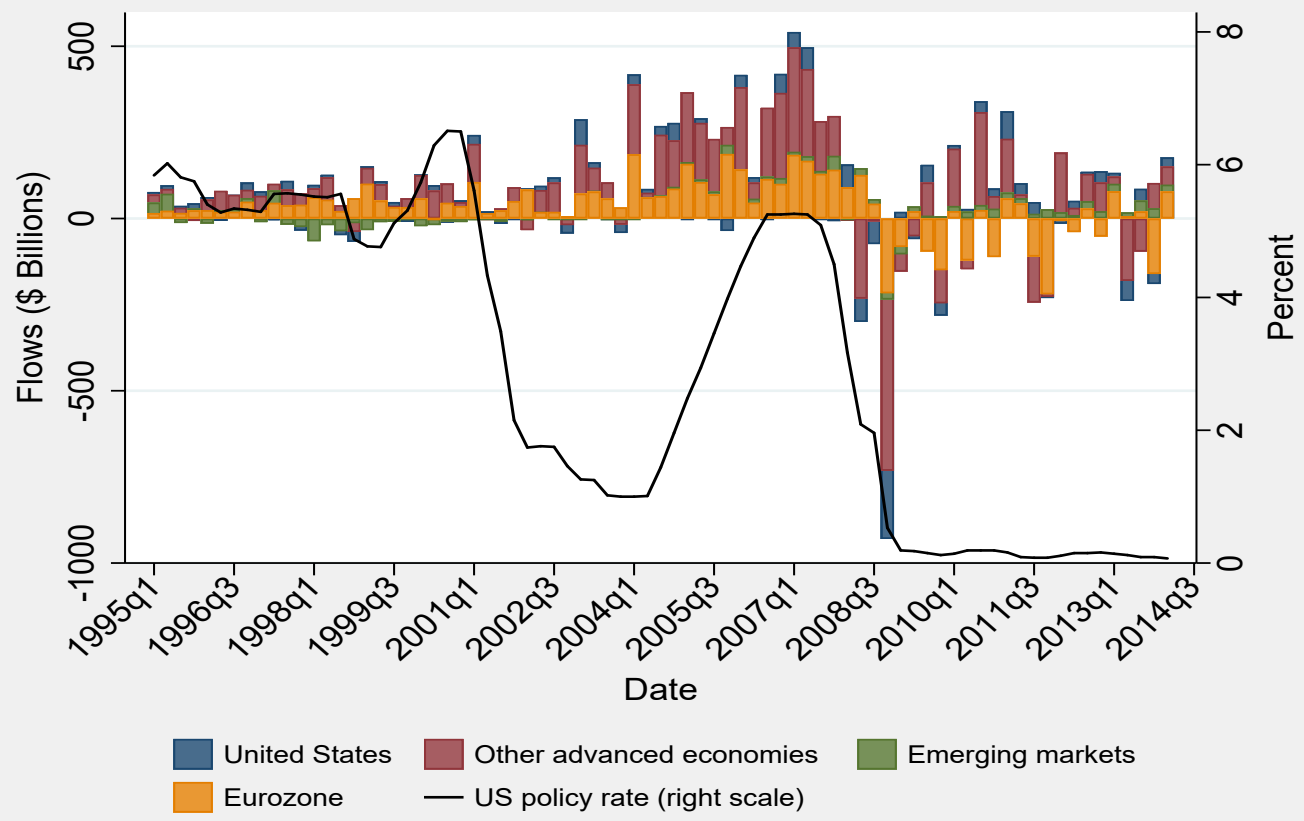

Note: The figure reports quarterly data between 1995:Q1 and 2014:Q2 for countries that report crossborder bank claims to the Bank for International Settlements for the entire sample period. The bars represent the quarterly exchange-rate and break-adjusted cross-border flows for reporting banking sectors aggregated into four regions: the United States, Eurozone, other advanced economies, and emerging markets. The Eurozone is composed of Austria, Belgium, Finland, France, Germany, Ireland, Italy, Luxembourg, Netherlands, and Spain. Other advanced economies are Canada, Denmark, Japan, Norway, Sweden, Switzerland, and the United Kingdom. Lastly, the Emerging markets group contains Hong Kong and Singapore. The black line plots the effective federal funds rate. 
Table 1: Sample Characteristics

This table reports summary statistics for cross-border bank flows, reporting and counterparty countries. All variables are defined in Appendix 1.

\begin{tabular}{|c|c|c|c|}
\hline & Mean & Median & StDev \\
\hline \multicolumn{4}{|c|}{ All Sample } \\
\hline Cross-border flows: All (\%) & 4.108 & 0.847 & 24.365 \\
\hline Cross-border flows: Banks (\%) & 9.039 & 0.504 & 46.983 \\
\hline Cross-border flows: Non-banks (\%) & 4.844 & 0.551 & 27.211 \\
\hline Domestic flows: Non-banks (\%) & 2.339 & 1.676 & 4.966 \\
\hline \multicolumn{4}{|c|}{ Reporting Countries } \\
\hline Policy rate rep & 3.074 & 2.58 & 3.211 \\
\hline Credit growth rep & 1.914 & 1.765 & 4.995 \\
\hline Bank equity returns rep & 2.62 & 3.053 & 16.742 \\
\hline Real GDP growth rep & 0.541 & 0.584 & 1.073 \\
\hline Debt/GDP rep & 65.9 & 61.19 & 39.225 \\
\hline Inflation rep & 0.553 & 0.489 & 0.821 \\
\hline QE indicator rep & 0.047 & 0.000 & 0.211 \\
\hline SRISK/GDP rep & 0.047 & 0.031 & 0.051 \\
\hline Euro rep & 0.399 & 0.000 & 0.49 \\
\hline Financial Center rep & 0.201 & 0.000 & 0.401 \\
\hline EME rep & 0.100 & 0.000 & 0.300 \\
\hline USD CB Liabilities/CB Liabilities rep & 0.100 & 0.000 & 0.300 \\
\hline \multicolumn{4}{|c|}{ Counterparty Countries } \\
\hline Policy rate $\mathrm{cp}$ & 5.905 & 2.58 & 3.211 \\
\hline Credit growth $\mathrm{cp}$ & 2.251 & 4.000 & 11.450 \\
\hline Bank equity returns $\mathrm{cp}$ & 3.524 & 3.159 & 19.155 \\
\hline Real GDP growth cp & 0.723 & 0.747 & 1.381 \\
\hline Debt/GDP cp & 56.409 & 48.88 & 35.446 \\
\hline Inflation cp & 1.171 & 0.665 & 4.947 \\
\hline SRISK/GDP cp & 0.03 & 0.007 & 0.044 \\
\hline Speculative grade & 0.21 & 0.000 & 0.407 \\
\hline EME cp & 0.127 & 0.000 & 0.333 \\
\hline VIX & 21.017 & 19.93 & 8.007 \\
\hline Exchange Rate Growth & 0.418 & 0.000 & 4.362 \\
\hline
\end{tabular}


Table 2: Cross-Border Bank Flows and Monetary Policy

The dependent variables are growth rates of cross-border flows to all sectors (banks and nonbanks), banks and non-banks. Each regression includes counterparty*year-quarter fixed effects. All variables are lagged one quarter. Variable definitions are listed in Appendix 1. Standard errors are clustered at the counterparty and reporting country levels. $* * *$ denotes $1 \%$ significant level, $* *$ denotes $5 \%$ significance level, and $*$ denotes $10 \%$ significance level.

\begin{tabular}{lccc}
\hline & All & Banks & Non-Banks \\
\hline & $(1)$ & $(2)$ & $(3)$ \\
\hline Lag policy rate rep & $0.330^{* * *}$ & $0.369^{* * *}$ & $0.426^{* * *}$ \\
& {$[0.068]$} & {$[0.095]$} & {$[0.136]$} \\
Lag credit growth rep & 0.023 & 0.105 & 0.064 \\
& {$[0.050]$} & {$[0.078]$} & {$[0.053]$} \\
Lag bank equity returns rep & -0.006 & -0.007 & -0.008 \\
& {$[0.011]$} & {$[0.020]$} & {$[0.011]$} \\
Lag real GDP growth rep & 0.160 & -0.101 & 0.107 \\
& {$[0.100]$} & {$[0.210]$} & {$[0.174]$} \\
Lag Debt/GDP rep & $-0.010^{* *}$ & $-0.026^{* * *}$ & -0.007 \\
& {$[0.004]$} & {$[0.007]$} & {$[0.005]$} \\
Lag inflation rep & -0.143 & 0.335 & 0.160 \\
& {$[0.269]$} & {$[0.496]$} & {$[0.417]$} \\
Exchange Rate Growth & $0.106^{*}$ & $0.178^{*}$ & $0.122^{* *}$ \\
& {$[0.057]$} & {$[0.095]$} & {$[0.053]$} \\
Financial Center rep & $-1.177^{*}$ & $-3.368^{* * *}$ & -1.382 \\
Euro rep & {$[0.667]$} & {$[1.029]$} & {$[0.823]$} \\
QE indicator rep & $-0.992^{* *}$ & -1.456 & $-1.745^{* * *}$ \\
EME rep & {$[0.390]$} & {$[0.921]$} & {$[0.554]$} \\
Observations & $1.332^{* *}$ & 1.262 & 1.317 \\
$R^{2}$ & {$[0.484]$} & {$[1.140]$} & {$[0.912]$} \\
& 0.814 & 1.701 & 0.818 \\
& {$[0.658]$} & {$[1.256]$} & {$[0.987]$} \\
& 72,249 & 69,854 & 70,643 \\
\hline
\end{tabular}


Table 3: Cross-Border Bank Flows and Monetary Policy: Before and After the Global Financial Crisis

The dependent variables are growth rates of cross-border flows to all sectors (banks and nonbanks), banks and non-banks. Each regression includes counterparty*year-quarter fixed effects. All variables are lagged one quarter. Variable definitions are listed in Appendix 1. Standard errors are clustered at the counterparty and reporting country levels. $* * *$ denotes $1 \%$ significant level, $* *$ denotes $5 \%$ significance level, and $*$ denotes $10 \%$ significance level.

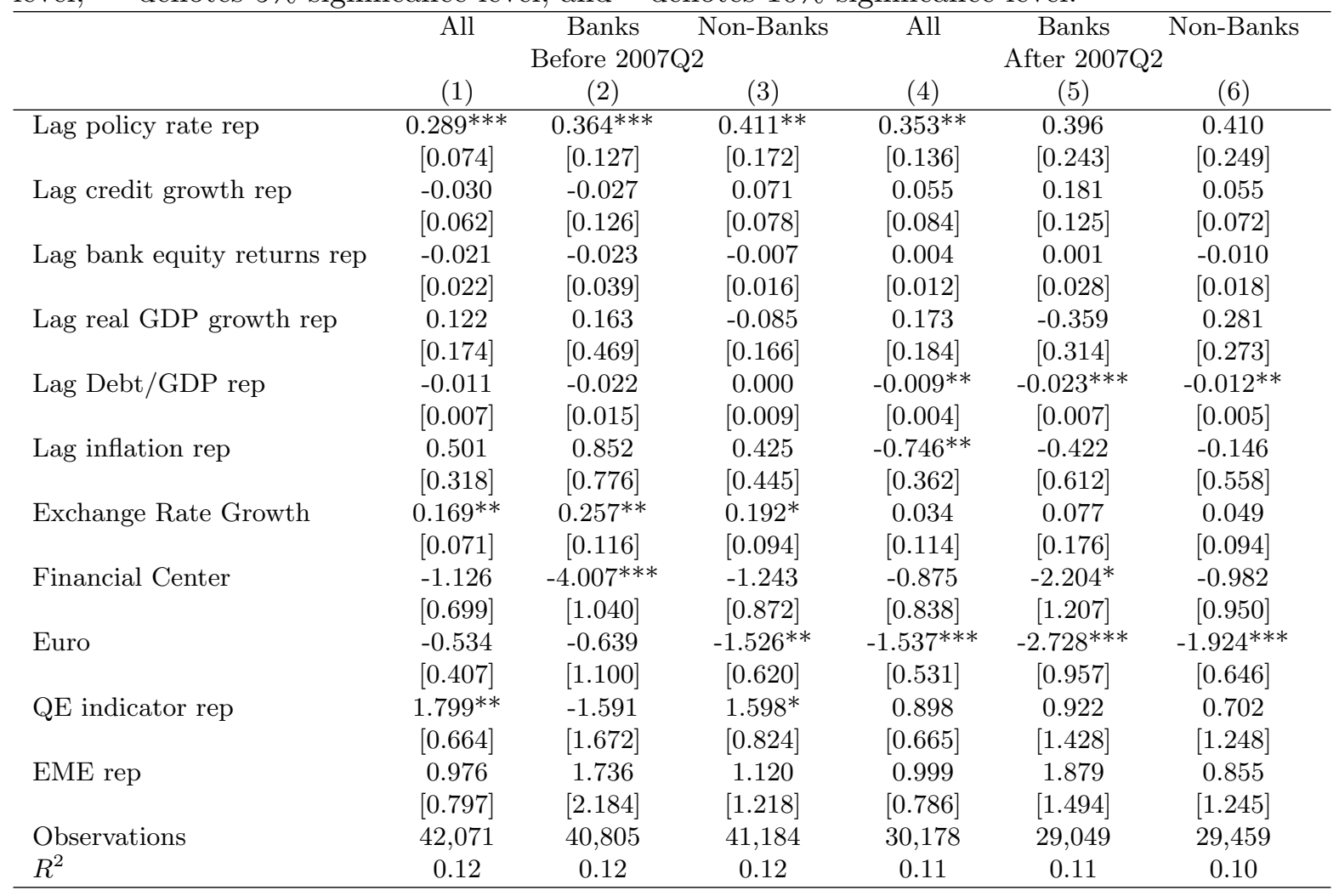




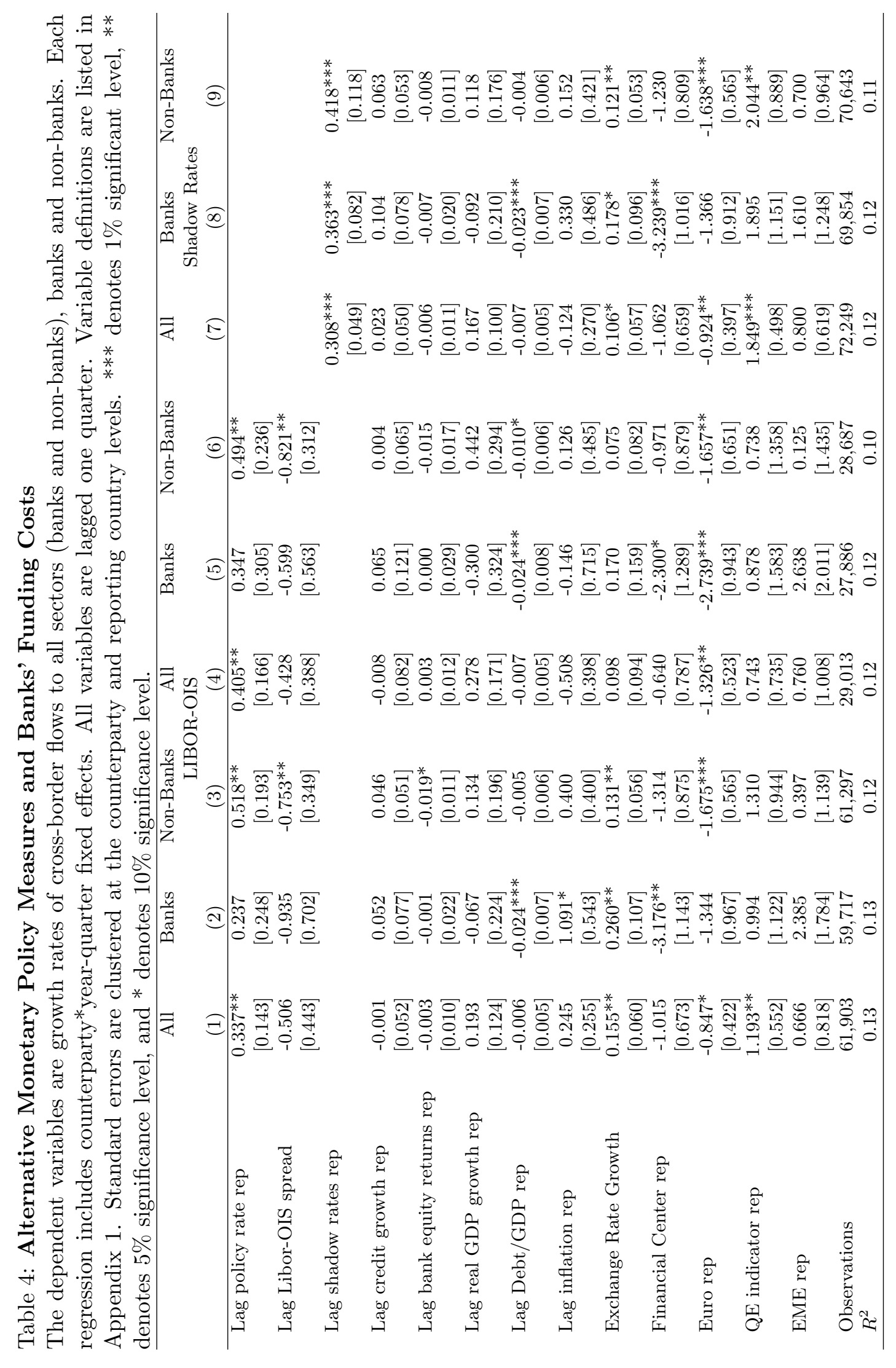




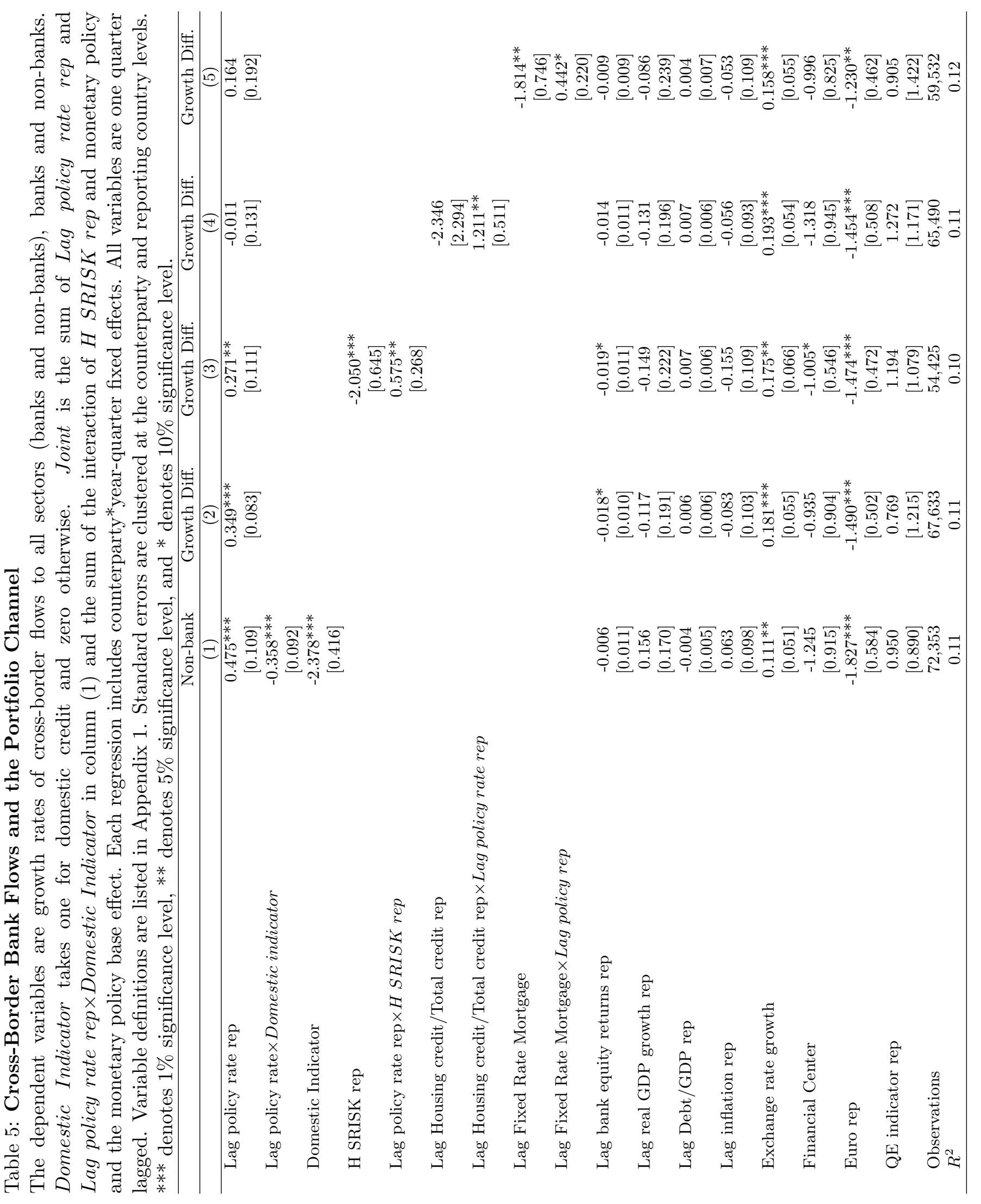


Table 6: Cross-Border Bank Flows to Speculative and Investment Grade Countries The dependent variables are growth rates of cross-border flows to all sectors (banks and nonbanks), banks and non-banks. Speculative grade cp takes one if the counterparty has noninvestment grade rating in a given year-quarter. Joint Speculative grade $c p$ is the sum of Lag policy rate rep and Lag policy rate rep* Speculative grade cp. Each regression includes counterparty*year-quarter fixed effects. All variables are one quarter lagged. Variable definitions are listed in Appendix 1. Standard errors are clustered at the counterparty and reporting country levels. ${ }^{* * *}$ denotes $1 \%$ significance level, ${ }^{* *}$ denotes $5 \%$ significance level, and ${ }^{*}$ denotes $10 \%$ significance level.

\begin{tabular}{|c|c|c|c|}
\hline & All & Banks & Non-Banks \\
\hline \multirow[t]{2}{*}{ Lag policy rate rep } & $0.404^{* * *}$ & $0.539^{* * *}$ & $0.457^{* * *}$ \\
\hline & {$[0.064]$} & {$[0.082]$} & {$[0.148]$} \\
\hline \multirow{2}{*}{ Lag policy rate rep $\times$ Speculative grade $c p$} & $-0.266^{* *}$ & $-0.709 * *$ & -0.035 \\
\hline & {$[0.117]$} & {$[0.279]$} & {$[0.172]$} \\
\hline \multirow[t]{2}{*}{ Lag credit growth rep } & 0.055 & 0.107 & $0.109^{*}$ \\
\hline & {$[0.061]$} & {$[0.091]$} & {$[0.061]$} \\
\hline \multirow[t]{2}{*}{ Lag credit growth $\mathrm{rep} \times$ Speculative grade $c p$} & -0.141 & -0.061 & $-0.182^{*}$ \\
\hline & {$[0.094]$} & {$[0.224]$} & {$[0.106]$} \\
\hline \multirow[t]{2}{*}{ Lag bank equity returns rep } & -0.013 & -0.020 & -0.013 \\
\hline & {$[0.014]$} & {$[0.022]$} & {$[0.014]$} \\
\hline \multirow[t]{2}{*}{ Lag bank equity returns rep $\times$ Speculative grade $c p$} & 0.028 & 0.057 & 0.024 \\
\hline & {$[0.021]$} & {$[0.058]$} & {$[0.020]$} \\
\hline \multirow[t]{2}{*}{ Lag real GDP growth rep } & 0.147 & 0.033 & 0.017 \\
\hline & {$[0.114]$} & {$[0.266]$} & {$[0.177]$} \\
\hline \multirow{2}{*}{ Lag real GDP growth rep $\times$ Speculative grade $c p$} & 0.348 & -0.307 & $0.817^{*}$ \\
\hline & {$[0.330]$} & {$[0.697]$} & {$[0.403]$} \\
\hline \multirow[t]{2}{*}{ Lag Debt/GDP rep } & $-0.010^{* *}$ & $-0.024^{* * *}$ & -0.006 \\
\hline & {$[0.005]$} & {$[0.008]$} & {$[0.007]$} \\
\hline \multirow[t]{2}{*}{ Lag Debt/GDP rep $\times$ Speculative grade $c p$} & 0.008 & 0.002 & -0.000 \\
\hline & [0.008] & {$[0.018]$} & {$[0.008]$} \\
\hline \multirow[t]{2}{*}{ Lag inflation rep } & -0.149 & 0.443 & 0.303 \\
\hline & {$[0.302]$} & {$[0.557]$} & {$[0.399]$} \\
\hline \multirow{2}{*}{ Lag inflation $\mathrm{rep} \times$ Speculative grade $c p$} & 0.435 & -0.197 & -0.348 \\
\hline & [0.369] & {$[0.971]$} & {$[0.237]$} \\
\hline \multirow[t]{2}{*}{ Exchange Rate Growth } & $0.122^{*}$ & $0.219^{* *}$ & 0.133 \\
\hline & {$[0.071]$} & {$[0.106]$} & {$[0.080]$} \\
\hline \multirow[t]{2}{*}{ Exchange Rate Growth $\times$ Speculative grade $c p$} & -0.120 & $-0.326^{*}$ & -0.113 \\
\hline & {$[0.092]$} & {$[0.186]$} & {$[0.118]$} \\
\hline \multirow[t]{2}{*}{ Financial Center rep } & $-1.715^{*}$ & $-4.155^{* * *}$ & -1.724 \\
\hline & {$[0.848]$} & {$[1.368]$} & [1.048] \\
\hline \multirow[t]{2}{*}{ Financial Center rep $\times$ Speculative grade $c p$} & $1.609^{*}$ & 2.371 & 0.684 \\
\hline & {$[0.830]$} & {$[2.071]$} & {$[1.175]$} \\
\hline \multirow[t]{2}{*}{ Euro rep } & -0.808 & -1.168 & $-1.600 * *$ \\
\hline & {$[0.490]$} & {$[0.928]$} & {$[0.691]$} \\
\hline \multirow[t]{2}{*}{ Euro rep $\times$ Speculative grade $c p$} & -0.872 & -2.326 & -0.632 \\
\hline & {$[0.618]$} & {$[1.746]$} & {$[0.804]$} \\
\hline \multirow[t]{2}{*}{ QE indicator rep } & $1.696^{* * *}$ & 1.786 & $1.543^{*}$ \\
\hline & {$[0.538]$} & {$[1.323]$} & {$[0.826]$} \\
\hline \multirow[t]{2}{*}{ QE indicator rep $\times$ Speculative grade $c p$} & -1.811 & -3.648 & -0.784 \\
\hline & {$[1.444]$} & {$[2.967]$} & {$[0.910]$} \\
\hline Observations & 69,232 & 67,050 & 67,646 \\
\hline$R^{2}$ & 0.11 & 0.11 & 0.10 \\
\hline Joint Speculative grade $\mathrm{cp}$ & 0.138 & -0.170 & $0.422^{* * *}$ \\
\hline t-statistic & 0.931 & -0.560 & 3.393 \\
\hline
\end{tabular}


Table 7: Cross-Border Bank Flows to Advanced Economies and Emerging Markets The dependent variables are growth rates of cross-border flows to all sectors (banks and non-banks), banks and non-banks. EME cp takes one if the counterparty is classified as a emerging market economy. Joint EME cp is the sum of Lag policy rate rep and Lag policy rate rep $\times E M E$ cp. Each regression includes counterparty*year-quarter fixed effects. All variables are one quarter lagged. Variable definitions are listed in Appendix 1. Standard errors are clustered at the counterparty and reporting country levels. $* * *$ denotes $1 \%$ significance level, ${ }^{* *}$ denotes $5 \%$ significance level, and $*$ denotes $10 \%$ significance level.

\begin{tabular}{|c|c|c|c|}
\hline & All & Banks & Non-Banks \\
\hline \multirow[t]{2}{*}{ Lag policy rate rep } & $0.448^{* * *}$ & $0.650^{* * *}$ & $0.373^{* *}$ \\
\hline & {$[0.059]$} & {$[0.102]$} & {$[0.154]$} \\
\hline \multirow[t]{2}{*}{ Lag policy rate $\operatorname{rep} \times E M E c p$} & $-0.295^{* *}$ & $-0.796^{* * *}$ & 0.231 \\
\hline & {$[0.116]$} & {$[0.247]$} & {$[0.241]$} \\
\hline \multirow[t]{2}{*}{ Lag credit growth rep } & 0.045 & 0.099 & 0.119 \\
\hline & {$[0.061]$} & {$[0.100]$} & {$[0.072]$} \\
\hline \multirow[t]{2}{*}{ Lag credit growth $\operatorname{rep} \times E M E c p$} & -0.036 & 0.022 & -0.095 \\
\hline & {$[0.063]$} & {$[0.111]$} & {$[0.076]$} \\
\hline \multirow[t]{2}{*}{ Lag bank equity returns rep } & -0.019 & -0.016 & 0.004 \\
\hline & {$[0.018]$} & {$[0.029]$} & {$[0.017]$} \\
\hline \multirow[t]{2}{*}{ Lag bank equity returns $\operatorname{rep} \times E M E c p$} & 0.024 & 0.020 & -0.024 \\
\hline & {$[0.025]$} & {$[0.049]$} & {$[0.024]$} \\
\hline \multirow{2}{*}{ Lag real GDP growth rep } & 0.048 & 0.045 & -0.194 \\
\hline & {$[0.178]$} & {$[0.374]$} & {$[0.243]$} \\
\hline \multirow[t]{2}{*}{ Lag real GDP growth $\mathrm{rep} \times E M E c p$} & 0.329 & -0.132 & $0.687^{*}$ \\
\hline & {$[0.238]$} & {$[0.519]$} & {$[0.367]$} \\
\hline \multirow[t]{2}{*}{ Lag Debt/GDP rep } & $-0.012^{*}$ & $-0.021^{*}$ & -0.009 \\
\hline & {$[0.006]$} & {$[0.012]$} & {$[0.009]$} \\
\hline \multirow[t]{2}{*}{ Lag Debt/GDP rep $\times E M E c p$} & 0.006 & -0.009 & 0.006 \\
\hline & {$[0.008]$} & {$[0.018]$} & {$[0.010]$} \\
\hline \multirow[t]{2}{*}{ Lag inflation rep } & -0.370 & 0.031 & 0.320 \\
\hline & [0.381] & {$[0.692]$} & {$[0.455]$} \\
\hline \multirow{2}{*}{ Lag inflation $\operatorname{rep} \times E M E c p$} & 0.624 & 0.979 & -0.203 \\
\hline & {$[0.394]$} & {$[0.879]$} & {$[0.400]$} \\
\hline \multirow[t]{2}{*}{ Exchange Rate Growth } & 0.116 & 0.186 & 0.127 \\
\hline & {$[0.086]$} & {$[0.140]$} & {$[0.086]$} \\
\hline \multirow[t]{2}{*}{ Exchange Rate Growth $\times E M E c p$} & -0.025 & -0.032 & -0.013 \\
\hline & {$[0.089]$} & {$[0.157]$} & {$[0.091]$} \\
\hline \multirow[t]{2}{*}{ Financial Center rep } & $-2.295^{* *}$ & $-5.590 * * *$ & -1.677 \\
\hline & {$[0.921]$} & {$[1.683]$} & {$[1.267]$} \\
\hline \multirow[t]{2}{*}{ Financial Center $\operatorname{rep} \times E M E c p$} & $1.894^{* * *}$ & $3.912^{* *}$ & 0.321 \\
\hline & {$[0.611]$} & {$[1.856]$} & {$[1.087]$} \\
\hline \multirow[t]{2}{*}{ Euro rep } & $-1.167^{* *}$ & -2.000 & $-2.134^{* *}$ \\
\hline & {$[0.541]$} & {$[1.215]$} & {$[0.842]$} \\
\hline \multirow[t]{2}{*}{ Euro rep $\times E M E c p$} & 0.176 & 0.722 & 0.615 \\
\hline & {$[0.645]$} & [1.996] & {$[0.885]$} \\
\hline \multirow[t]{2}{*}{ QE indicator rep } & 0.839 & 0.392 & 0.186 \\
\hline & {$[0.655]$} & {$[1.388]$} & {$[0.852]$} \\
\hline \multirow[t]{2}{*}{ QE indicator $\operatorname{rep} \times E M E c p$} & 0.383 & 0.472 & 1.896 \\
\hline & [0.998] & {$[1.841]$} & {$[1.580]$} \\
\hline Observations & 72,249 & 69,854 & 70,643 \\
\hline$R^{2}$ & 0.12 & 0.12 & 0.11 \\
\hline Joint EME cp & 0.153 & -0.147 & $0.604^{* * *}$ \\
\hline t-statistic & 1.076 & -0.597 & 4.009 \\
\hline
\end{tabular}


Table 8: Cross-Border Bank Flows to Eurozone Counterparties

The dependent variables are growth rates of cross-border flows to all sectors (banks and nonbanks), banks and non-banks. Each regression includes counterparty*year-quarter fixed effects. All variables are lagged one quarter. Variable definitions are listed in Appendix 1. Euro rep takes one for Eurozone reporting countries and zero otherwise. Standard errors are clustered at the counterparty and reporting country levels. ${ }^{* * *}$ denotes $1 \%$ significance level, ${ }^{* *}$ denotes $5 \%$ significance level, and $*$ denotes $10 \%$ significance level.

\begin{tabular}{|c|c|c|c|c|c|c|}
\hline & \multirow[t]{2}{*}{ All } & \multirow[t]{2}{*}{ Banks } & \multirow[t]{2}{*}{ Non-Banks } & All & Banks & Non-Banks \\
\hline & & & & \multicolumn{3}{|c|}{ Excluding Germany and France } \\
\hline & $(1)$ & $(2)$ & $(3)$ & $(4)$ & $(5)$ & (6) \\
\hline \multirow[t]{2}{*}{ Lag policy rate rep } & $0.373^{* * *}$ & $0.458^{* * *}$ & $0.458^{* * *}$ & $0.389^{* * *}$ & $0.480 * * *$ & $0.468^{* * *}$ \\
\hline & {$[0.059]$} & {$[0.110]$} & {$[0.140]$} & {$[0.063]$} & {$[0.117]$} & {$[0.145]$} \\
\hline \multirow[t]{2}{*}{ Lag policy rate rep $\times$ Euro $r e p$} & $0.400^{*}$ & $0.665^{* *}$ & 0.231 & $0.581^{* * *}$ & $0.844^{* *}$ & 0.381 \\
\hline & {$[0.200]$} & {$[0.308]$} & {$[0.270]$} & [0.203] & {$[0.349]$} & {$[0.302]$} \\
\hline \multirow[t]{2}{*}{ Lag credit growth rep } & -0.006 & 0.095 & 0.078 & -0.006 & 0.046 & 0.067 \\
\hline & {$[0.004]$} & {$[0.111]$} & {$[0.052]$} & {$[0.055]$} & {$[0.113]$} & {$[0.051]$} \\
\hline \multirow[t]{2}{*}{ Lag credit growth rep $\times$ Euro rep } & -0.001 & -0.021 & -0.051 & -0.015 & -0.042 & -0.059 \\
\hline & {$[0.066]$} & {$[0.107]$} & {$[0.063]$} & {$[0.073]$} & {$[0.119]$} & {$[0.073]$} \\
\hline \multirow[t]{2}{*}{ Lag bank equity returns rep } & -0.006 & -0.008 & 0.003 & -0.007 & -0.002 & 0.001 \\
\hline & {$[0.017]$} & {$[0.040]$} & {$[0.017]$} & {$[0.017]$} & {$[0.039]$} & {$[0.019]$} \\
\hline \multirow[t]{2}{*}{ Lag bank equity returns rep $\times$ Euro $r e p$} & 0.001 & 0.005 & -0.02 & 0.003 & 0.001 & -0.011 \\
\hline & {$[0.016]$} & [0.039] & {$[0.022]$} & {$[0.015]$} & [0.049] & {$[0.023]$} \\
\hline \multirow[t]{2}{*}{ Lag real GDP growth rep } & 0.192 & -0.111 & 0.048 & 0.126 & -0.243 & -0.011 \\
\hline & {$[0.204]$} & {$[0.325]$} & {$[0.329]$} & {$[0.212]$} & {$[0.338]$} & {$[0.340]$} \\
\hline \multirow[t]{2}{*}{ Lag real GDP growth rep $\times$ Euro rep } & -0.078 & 0.154 & 0.139 & -0.031 & 0.174 & 0.178 \\
\hline & {$[0.258]$} & {$[0.412]$} & {$[0.382]$} & {$[0.270]$} & {$[0.440]$} & {$[0.393]$} \\
\hline \multirow[t]{2}{*}{ Lag Debt/GDP rep } & -0.006 & $-0.024^{* * *}$ & -0.006 & -0.007 & $-0.027^{* * *}$ & -0.007 \\
\hline & {$[0.004]$} & {$[0.008]$} & {$[0.007]$} & {$[0.005]$} & {$[0.006]$} & {$[0.007]$} \\
\hline \multirow{2}{*}{ Lag Debt/GDP rep $\times$ Euro rep } & -0.001 & -0.007 & -0.009 & $-0.022^{*}$ & -0.018 & -0.011 \\
\hline & {$[0.066]$} & {$[0.035]$} & {$[0.015]$} & {$[0.012]$} & {$[0.028]$} & {$[0.013]$} \\
\hline \multirow[t]{2}{*}{ Lag inflation rep } & -0.257 & 0.244 & 0.043 & -0.325 & 0.018 & -0.045 \\
\hline & {$[0.331]$} & {$[0.565]$} & {$[0.495]$} & [0.338] & {$[0.553]$} & {$[0.494]$} \\
\hline \multirow[t]{2}{*}{ Lag inflation $\mathrm{rep} \times$ Euro $r e p$} & 0.411 & 0.635 & 0.484 & 0.163 & 0.166 & 0.093 \\
\hline & {$[0.590]$} & {$[1.116]$} & {$[0.695]$} & {$[0.626]$} & [1.118] & {$[0.707]$} \\
\hline \multirow[t]{2}{*}{ Exchange Rate Growth } & 0.096 & 0.14 & $0.119^{*}$ & 0.093 & 0.127 & $0.122^{*}$ \\
\hline & {$[0.063]$} & {$[0.111]$} & {$[0.061]$} & {$[0.064]$} & {$[0.121]$} & {$[0.066]$} \\
\hline \multirow[t]{2}{*}{ Exchange Rate Growth $\times$ Euro rep } & 0.022 & 0.137 & -0.006 & -0.002 & 0.151 & -0.085 \\
\hline & {$[0.076]$} & {$[0.126]$} & {$[0.074]$} & {$[0.087]$} & {$[0.139]$} & {$[0.066]$} \\
\hline \multirow[t]{2}{*}{ Financial Center rep } & -1.01 & $-3.773^{* * *}$ & -1.224 & -1.093 & $-3.948^{* * *}$ & -1.354 \\
\hline & {$[0.805]$} & {$[1.197]$} & {$[1.067]$} & {$[0.853]$} & {$[1.293]$} & {$[1.125]$} \\
\hline \multirow[t]{2}{*}{ Financial Center rep $\times$ Euro rep } & -1.192 & 1.145 & -0.914 & -1.708 & -0.551 & -1.419 \\
\hline & {$[1.170]$} & {$[2.326]$} & {$[1.456]$} & {$[1.151]$} & {$[2.155]$} & {$[1.416]$} \\
\hline \multirow[t]{2}{*}{ QE indicator rep } & $0.776^{*}$ & 0.875 & 0.989 & $0.843^{* *}$ & 0.975 & 1.138 \\
\hline & {$[0.412]$} & {$[0.709]$} & {$[1.003]$} & {$[0.384]$} & {$[0.817]$} & {$[0.940]$} \\
\hline \multirow[t]{2}{*}{ EME rep } & 0.381 & 0.192 & 0.599 & 0.491 & 0.666 & 0.694 \\
\hline & {$[0.808]$} & {$[1.167]$} & {$[1.322]$} & {$[0.817]$} & {$[1.165]$} & {$[1.292]$} \\
\hline EME rep $\times$ Euro rep & $2.571^{*}$ & $5.603^{* *}$ & 1.527 & $2.381^{*}$ & $4.632^{* *}$ & 1.347 \\
\hline & [1.333] & {$[2.445]$} & [1.195] & {$[1.259]$} & {$[2.038]$} & {$[1.122]$} \\
\hline Euro rep & -0.871 & -3.351 & -1.87 & -0.442 & -1.415 & -1.314 \\
\hline & {$[1.416]$} & {$[3.055]$} & {$[1.690]$} & {$[1.377]$} & {$[2.729]$} & {$[1.550]$} \\
\hline Observations & 72,249 & 69,854 & 70,643 & 61,694 & 59,329 & 60,187 \\
\hline$R^{2}$ & 0.12 & 0.12 & 0.11 & 0.12 & 0.13 & 0.12 \\
\hline Coef. Policy Rate Euro cp & 0.774 & 1.123 & 0.689 & 0.97 & 1.323 & 0.849 \\
\hline t-statistic & 3.903 & 3.391 & 2.146 & 5.001 & 3.505 & 2.444 \\
\hline
\end{tabular}


Table 9: Cross-Border Bank Flows in "Good Times" and "Bad Times"

The dependent variables are growth rates of cross-border flows to all sectors (banks and nonbanks), banks and non-banks. Each regression includes counterparty*year-quarter fixed effects. All variables are lagged one quarter. Variable definitions are listed in Appendix 1. HGDP rep takes one if GDP growth is higher than the sample median and zero otherwise. Standard errors are clustered at the counterparty and reporting country levels. $* * *$ denotes $1 \%$ significance level, $* *$ denotes $5 \%$ significance level, and $*$ denotes $10 \%$ significance level.

\begin{tabular}{|c|c|c|c|}
\hline & All & Banks & Non-Banks \\
\hline \multirow[t]{2}{*}{ Lag policy rate rep } & $0.435^{* * *}$ & $0.391^{*}$ & $0.495^{* *}$ \\
\hline & {$[0.102]$} & {$[0.212]$} & {$[0.183]$} \\
\hline \multirow[t]{2}{*}{ Lag policy rate $\mathrm{rep} \times H G D P$ rep } & -0.160 & -0.051 & -0.087 \\
\hline & {$[0.144]$} & {$[0.277]$} & {$[0.127]$} \\
\hline \multirow[t]{2}{*}{ Lag credit growth rep } & 0.038 & 0.091 & 0.100 \\
\hline & {$[0.051]$} & {$[0.080]$} & {$[0.075]$} \\
\hline \multirow[t]{2}{*}{ Lag credit growth $\operatorname{rep} \times H G D P$ rep } & -0.030 & 0.023 & -0.050 \\
\hline & [0.049] & {$[0.082]$} & {$[0.052]$} \\
\hline \multirow[t]{2}{*}{ Lag bank equity returns rep } & -0.009 & 0.002 & -0.015 \\
\hline & {$[0.011]$} & {$[0.028]$} & {$[0.013]$} \\
\hline \multirow{2}{*}{ Lag bank equity returns $\mathrm{rep} \times H G D P$ rep } & 0.005 & -0.012 & 0.011 \\
\hline & {$[0.016]$} & {$[0.031]$} & {$[0.019]$} \\
\hline \multirow[t]{2}{*}{ Lag real GDP growth rep } & 0.250 & -0.291 & 0.468 \\
\hline & [0.199] & {$[0.421]$} & {$[0.310]$} \\
\hline \multirow{2}{*}{ Lag real GDP growth $\mathrm{rep} \times H G D P$ rep } & -0.035 & 0.065 & -0.161 \\
\hline & {$[0.306]$} & {$[0.516]$} & {$[0.481]$} \\
\hline \multirow[t]{2}{*}{ Lag Debt/GDP rep } & -0.005 & $-0.022^{* *}$ & -0.011 \\
\hline & {$[0.005]$} & {$[0.008]$} & {$[0.008]$} \\
\hline \multirow{2}{*}{ Lag Debt/GDP rep $\times H G D P$ rep } & -0.010 & -0.008 & 0.007 \\
\hline & {$[0.007]$} & {$[0.010]$} & {$[0.009]$} \\
\hline \multirow[t]{2}{*}{ Lag inflation rep } & -0.208 & 0.864 & -0.481 \\
\hline & {$[0.321]$} & {$[0.723]$} & {$[0.488]$} \\
\hline \multirow[t]{2}{*}{ Lag inflation rep $\times H G D P$ rep } & 0.023 & -0.836 & 0.983 \\
\hline & [0.469] & {$[0.926]$} & {$[0.672]$} \\
\hline \multirow{2}{*}{ Exchange Rate Growth } & 0.071 & 0.154 & 0.043 \\
\hline & {$[0.058]$} & {$[0.116]$} & {$[0.063]$} \\
\hline \multirow{2}{*}{ Exchange Rate Growth $\times H G D P r e p$} & 0.056 & 0.042 & $0.133^{* * *}$ \\
\hline & {$[0.050]$} & {$[0.128]$} & {$[0.041]$} \\
\hline \multirow[t]{2}{*}{ Financial Center rep } & -0.619 & $-2.875^{*}$ & $-1.513^{*}$ \\
\hline & {$[0.850]$} & {$[1.630]$} & {$[0.785]$} \\
\hline \multirow[t]{2}{*}{ Financial Center rep $\times H G D P$ rep } & -1.042 & -0.974 & 0.244 \\
\hline & {$[0.621]$} & {$[1.440]$} & {$[0.728]$} \\
\hline \multirow[t]{2}{*}{ Euro rep } & $-0.926^{* *}$ & -1.063 & $-2.053^{* *}$ \\
\hline & {$[0.416]$} & {$[1.082]$} & {$[0.758]$} \\
\hline \multirow[t]{2}{*}{ Euro rep $\times H G D P$ rep } & -0.038 & -0.773 & 0.616 \\
\hline & {$[0.503]$} & {$[1.005]$} & {$[0.710]$} \\
\hline \multirow[t]{2}{*}{ QE indicator rep } & 0.779 & 1.346 & 0.497 \\
\hline & {$[0.541]$} & {$[1.351]$} & {$[0.803]$} \\
\hline \multirow{2}{*}{ QE indicator $\mathrm{rep} \times H G D P$ rep } & 1.301 & -0.102 & $1.706^{*}$ \\
\hline & {$[0.998]$} & {$[1.766]$} & {$[0.860]$} \\
\hline \multirow[t]{2}{*}{ EME rep } & 0.551 & 2.518 & 1.431 \\
\hline & {$[1.171]$} & {$[2.540]$} & {$[1.793]$} \\
\hline \multirow[t]{2}{*}{ EME rep $\times H G D P$ rep } & 0.459 & -1.090 & -0.857 \\
\hline & {$[1.438]$} & {$[2.866]$} & {$[1.621]$} \\
\hline \multirow{2}{*}{ H GDP } & 1.119 & 2.101 & -1.606 \\
\hline & {$[0.882]$} & [1.638] & {$[1.327]$} \\
\hline Observations & 72,249 & 69,854 & 70,643 \\
\hline$R^{2}$ & 0.12 & 0.12 & 0.11 \\
\hline
\end{tabular}


Table 10: Cross-Border Flows during Currency Appreciation and Currency Depreciation Episodes

The dependent variables are growth rates of cross-border flows to all sectors (banks and nonbanks), banks and non-banks. Each regression includes counterparty*year-quarter fixed effects. All variables are lagged one quarter. Variable definitions are listed in Appendix 1. Appr takes one for currency appreciation and zero otherwise. Standard errors are clustered at the counterparty and reporting country levels. $* * *$ denotes $1 \%$ significance level, ${ }^{* *}$ denotes $5 \%$ significance level, and $*$ denotes $10 \%$ significance level.

\begin{tabular}{|c|c|c|c|}
\hline & All & Banks & Non-Banks \\
\hline \multirow[t]{2}{*}{ Lag policy rate rep } & $0.383^{* * *}$ & $0.481^{* *}$ & $0.416^{* *}$ \\
\hline & {$[0.113]$} & {$[0.203]$} & {$[0.152]$} \\
\hline \multirow{2}{*}{ Lag policy rate $\operatorname{rep} \times A p p r$} & -0.105 & -0.242 & -0.000 \\
\hline & {$[0.208]$} & {$[0.310]$} & {$[0.181]$} \\
\hline \multirow[t]{2}{*}{ Lag credit growth rep } & 0.008 & 0.057 & 0.071 \\
\hline & {$[0.060]$} & {$[0.109]$} & {$[0.055]$} \\
\hline \multirow[t]{2}{*}{ Lag credit growth $\operatorname{rep} \times A p p r$} & 0.037 & 0.110 & -0.010 \\
\hline & {$[0.068]$} & {$[0.125]$} & {$[0.070]$} \\
\hline \multirow[t]{2}{*}{ Lag bank equity returns rep } & -0.003 & -0.006 & 0.002 \\
\hline & {$[0.011]$} & {$[0.026]$} & {$[0.020]$} \\
\hline \multirow[t]{2}{*}{ Lag bank equity returns $\operatorname{rep} \times A p p r$} & -0.010 & -0.005 & -0.026 \\
\hline & {$[0.018]$} & {$[0.035]$} & {$[0.021]$} \\
\hline \multirow[t]{2}{*}{ Lag real GDP growth rep } & -0.048 & -0.480 & -0.054 \\
\hline & {$[0.196]$} & {$[0.390]$} & {$[0.229]$} \\
\hline \multirow[t]{2}{*}{ Lag real GDP growth rep $\times A p p r$} & $0.535^{*}$ & 0.943 & 0.449 \\
\hline & {$[0.286]$} & {$[0.635]$} & {$[0.357]$} \\
\hline \multirow{2}{*}{ Lag Debt/GDP rep } & $-0.011^{*}$ & $-0.035 * * *$ & -0.009 \\
\hline & {$[0.005]$} & {$[0.012]$} & {$[0.006]$} \\
\hline \multirow{2}{*}{ Lag Debt/GDP rep $\times A p p r$} & 0.003 & 0.018 & 0.002 \\
\hline & {$[0.007]$} & {$[0.015]$} & {$[0.007]$} \\
\hline \multirow[t]{2}{*}{ Lag inflation rep } & -0.295 & 0.454 & -0.369 \\
\hline & {$[0.434]$} & {$[0.639]$} & {$[0.594]$} \\
\hline \multirow[t]{2}{*}{ Lag inflation $\operatorname{rep} \times A p p r$} & 0.299 & -0.283 & $1.092^{*}$ \\
\hline & {$[0.699]$} & {$[1.140]$} & {$[0.546]$} \\
\hline \multirow[t]{2}{*}{ Exchange Rate Growth } & 0.116 & -0.097 & $0.224^{* *}$ \\
\hline & {$[0.095]$} & {$[0.141]$} & {$[0.087]$} \\
\hline \multirow{2}{*}{ Exchange Rate Growth $\times A p p r$} & -0.059 & $0.463^{* *}$ & -0.193 \\
\hline & {$[0.125]$} & {$[0.204]$} & {$[0.121]$} \\
\hline \multirow[t]{2}{*}{ Financial Center rep } & $-1.330^{*}$ & $-4.205^{* * *}$ & $-1.594^{* *}$ \\
\hline & {$[0.744]$} & {$[1.320]$} & {$[0.725]$} \\
\hline \multirow[t]{2}{*}{ Financial Center $\operatorname{rep} \times A p p r$} & 0.382 & $1.932^{*}$ & 0.483 \\
\hline & {$[0.639]$} & {$[1.116]$} & {$[0.544]$} \\
\hline \multirow[t]{2}{*}{ Euro rep } & $-0.933^{* *}$ & -1.586 & $-1.864^{* * *}$ \\
\hline & {$[0.435]$} & [1.038] & {$[0.567]$} \\
\hline \multirow[t]{2}{*}{ Euro rep $\times A p p r$} & -0.049 & 1.028 & 0.103 \\
\hline & {$[0.547]$} & {$[0.942]$} & {$[0.611]$} \\
\hline \multirow[t]{2}{*}{ QE indicator rep } & $2.122^{* *}$ & 2.643 & $2.024^{* *}$ \\
\hline & {$[0.821]$} & {$[1.637]$} & {$[0.978]$} \\
\hline \multirow[t]{2}{*}{ QE indicator $r e p \times A p p r$} & -1.583 & -2.787 & -1.460 \\
\hline & {$[1.214]$} & {$[1.788]$} & {$[1.140]$} \\
\hline \multirow[t]{2}{*}{ EME rep } & 0.362 & 0.458 & 1.125 \\
\hline & {$[0.724]$} & {$[2.271]$} & {$[1.269]$} \\
\hline \multirow[t]{2}{*}{ EME $\operatorname{rep} \times A p p r$} & 1.025 & 2.778 & -0.617 \\
\hline & {$[1.257]$} & {$[2.842]$} & {$[1.544]$} \\
\hline \multirow{2}{*}{ Appr } & -0.179 & -1.548 & -0.882 \\
\hline & {$[1.009]$} & {$[1.760]$} & {$[1.150]$} \\
\hline Observations & 72,249 & 69,854 & 70,643 \\
\hline$R^{2}$ & 0.12 & 0.12 & 0.11 \\
\hline
\end{tabular}




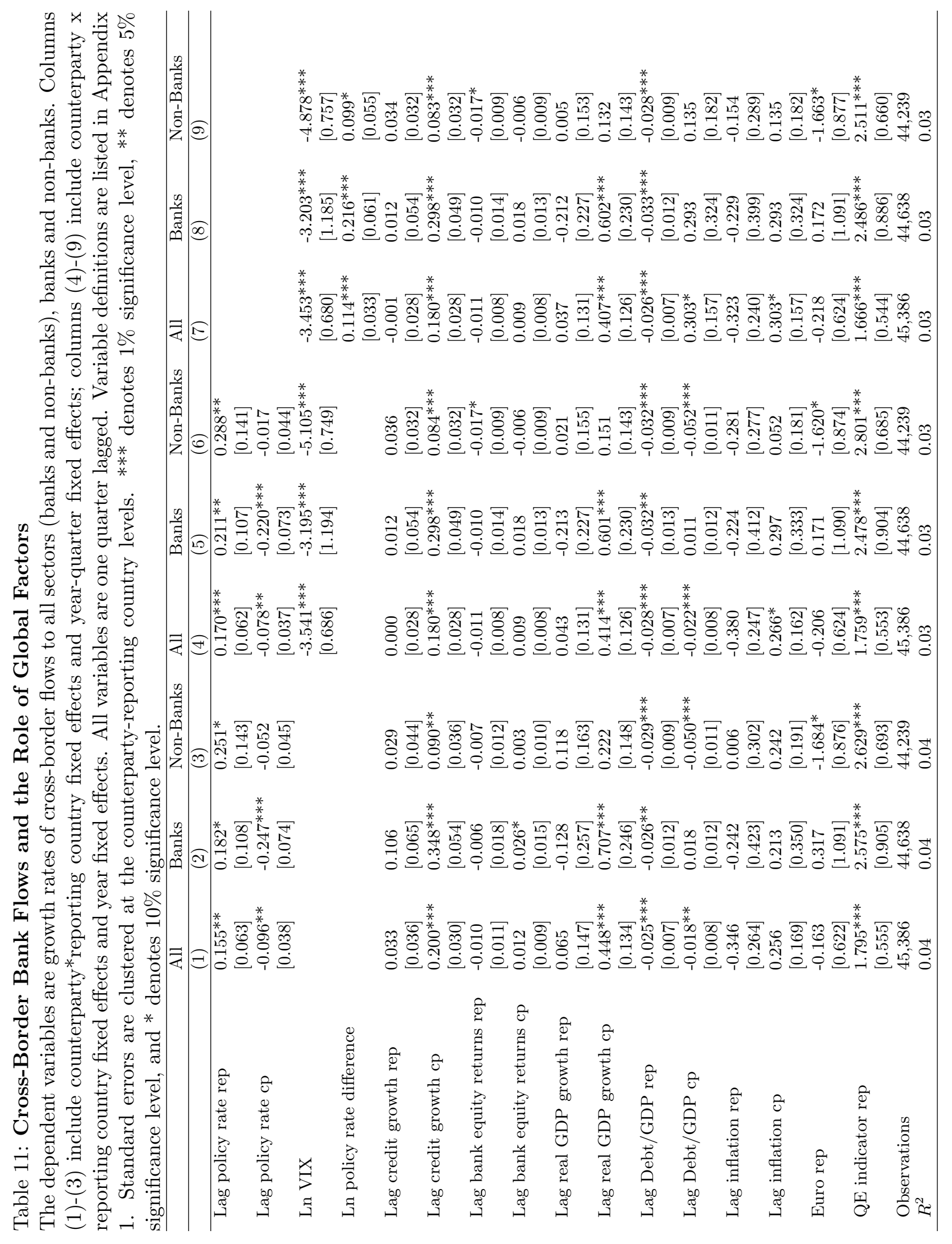


Table 12: Cross-Border Bank Flows and the Role of U.S. Dollar Funding

The dependent variables are growth rates of cross-border flows to all sectors (banks and nonbanks), banks and non-banks. USD CB Liabilities/CB Liabilities rep is the ratio of crossborder liabilities denominated in US dollars over cross-border liabilities. Each regression includes counterparty*year-quarter fixed effects. All variables are one quarter lagged. Variable definitions are listed in Appendix 1. Standard errors are clustered at the counterparty and reporting country levels. ${ }^{* * *}$ denotes $1 \%$ significance level, ${ }^{* *}$ denotes $5 \%$ significance level, and $*$ denotes $10 \%$ significance level.

\begin{tabular}{|c|c|c|c|}
\hline & All & Banks & Non-Banks \\
\hline \multirow[t]{2}{*}{ Lag policy rate rep } & $0.291^{* * *}$ & $0.329^{* * *}$ & $0.415^{* * *}$ \\
\hline & {$[0.071]$} & {$[0.118]$} & {$[0.139]$} \\
\hline \multirow{2}{*}{ USD CB Liabilities/CB Liabilities rep } & $3.332^{* *}$ & 2.562 & 2.300 \\
\hline & {$[1.478]$} & {$[3.497]$} & [1.953] \\
\hline \multirow{2}{*}{ Lag US policy rate rep $\times U S D C B$ Liabilities $/ C B$ Liabilities rep } & -0.522 & -0.079 & -0.778 \\
\hline & {$[0.365]$} & {$[0.562]$} & {$[0.470]$} \\
\hline \multirow[t]{2}{*}{ Lag credit growth rep } & 0.044 & 0.123 & 0.068 \\
\hline & {$[0.049]$} & {$[0.080]$} & {$[0.059]$} \\
\hline \multirow[t]{2}{*}{ Lag bank equity returns rep } & -0.014 & -0.020 & -0.009 \\
\hline & {$[0.011]$} & {$[0.019]$} & {$[0.012]$} \\
\hline \multirow{2}{*}{ Lag real GDP growth rep } & 0.122 & -0.143 & 0.052 \\
\hline & {$[0.109]$} & {$[0.219]$} & {$[0.174]$} \\
\hline \multirow[t]{2}{*}{ Lag Debt/GDP rep } & $-0.013^{* * *}$ & $-0.030 * * *$ & $-0.010^{*}$ \\
\hline & {$[0.005]$} & {$[0.010]$} & {$[0.006]$} \\
\hline \multirow[t]{2}{*}{ Lag inflation rep } & -0.130 & 0.446 & 0.119 \\
\hline & {$[0.270]$} & {$[0.509]$} & {$[0.415]$} \\
\hline \multirow[t]{2}{*}{ Exchange Rate Growth } & $0.120^{*}$ & $0.225^{* *}$ & $0.101^{*}$ \\
\hline & {$[0.064]$} & {$[0.092]$} & {$[0.057]$} \\
\hline \multirow[t]{2}{*}{ Financial Center } & $-1.881 * * *$ & $-4.185^{* * *}$ & $-2.096^{* * *}$ \\
\hline & {$[0.373]$} & {$[0.915]$} & {$[0.641]$} \\
\hline \multirow[t]{2}{*}{ Euro rep } & -0.363 & -0.784 & $-1.576^{* * *}$ \\
\hline & {$[0.476]$} & {$[1.375]$} & {$[0.536]$} \\
\hline \multirow[t]{2}{*}{ EME rep } & $1.205^{* * *}$ & 0.593 & 0.558 \\
\hline & {$[0.366]$} & {$[1.227]$} & {$[0.822]$} \\
\hline \multirow[t]{2}{*}{ QE indicator rep } & 0.895 & 1.785 & 0.768 \\
\hline & {$[0.596]$} & {$[1.316]$} & {$[0.979]$} \\
\hline Observations & 68,238 & 65,851 & 66,671 \\
\hline$R^{2}$ & 0.12 & 0.12 & 0.12 \\
\hline
\end{tabular}




\section{Appendix 1: Definition of Variables}

Bank equity returns rep/cp is stock returns of the banking sector. Source: Haver.

Credit growth rep/cp is credit growth of the domestic non-financial sector. Source: Bank of International Settlements.

Cross-border flows to all sectors, banks and non-banks is the ratio of quarterly flows adjusted for exchange rate changes to the previous quarter outstanding amounts, respectively to all sectors, banks and non-banks; winsorized at the 2.5 percentile. Source: Bank of International Settlements.

Debt/GDP rep/cp gross debt to GDP reporting/counterparty countries. It is gross debt as a percentage of nominal GDP for reporting countries. Source, IMF, World Economic Outlook, Haver

EME rep/cp is an indicator variable that takes one if a country is classified as an emerging economy and zero otherwise.

Exchange rate growth is quarter-over-quarter growth rate of nominal exchange rates of the reporting vis-a-vis the counterparty. Positive values show counterparty currency appreciation. Source: Bloomberg, Haver, New York Fed, Datastream.

Euro rep/cp is one if a reporting/counterparty country is one and zero otherwise.

Financial center rep is an indicator variable that takes one if the reporting country is a financial center (US, US, Hong Kong, Singapore and Luxembourg) and zero otherwise.

Inflation rep/cp is the quarter-over-quarter inflation for the reporting/counterparty country calculated using consumer price indices. Source: Haver.

Policy rate rep/cp is the monetary policy rate of reporting/counterparty countries. Source: Central banks, international monetary fund, CEIC.

Real GDP growth rep/cp is the real quarter-over-quarter real/chained GDP growth for reporting/counteryparty countries.

SRISK/GDP rep is the ratio of SRISK defined in Brownless and Engle (2017) over GDP.

USD CB liabilities/CB liabilities rep is the ratio of cross-border liabilities denominated in US dollars over cross-border liabilities.

QE indicator rep takes one if a counting country has a quantitative easing program.

VIX is a measure of market expectation of stock market volatility over the next 30-day period. It is calculated by the Chicago Board Options Exchange (CBOE), often referred to as the fear index. 


\section{Appendix 2}

Figure A2.1: Monetary Policy Rate for Different Economic Conditions

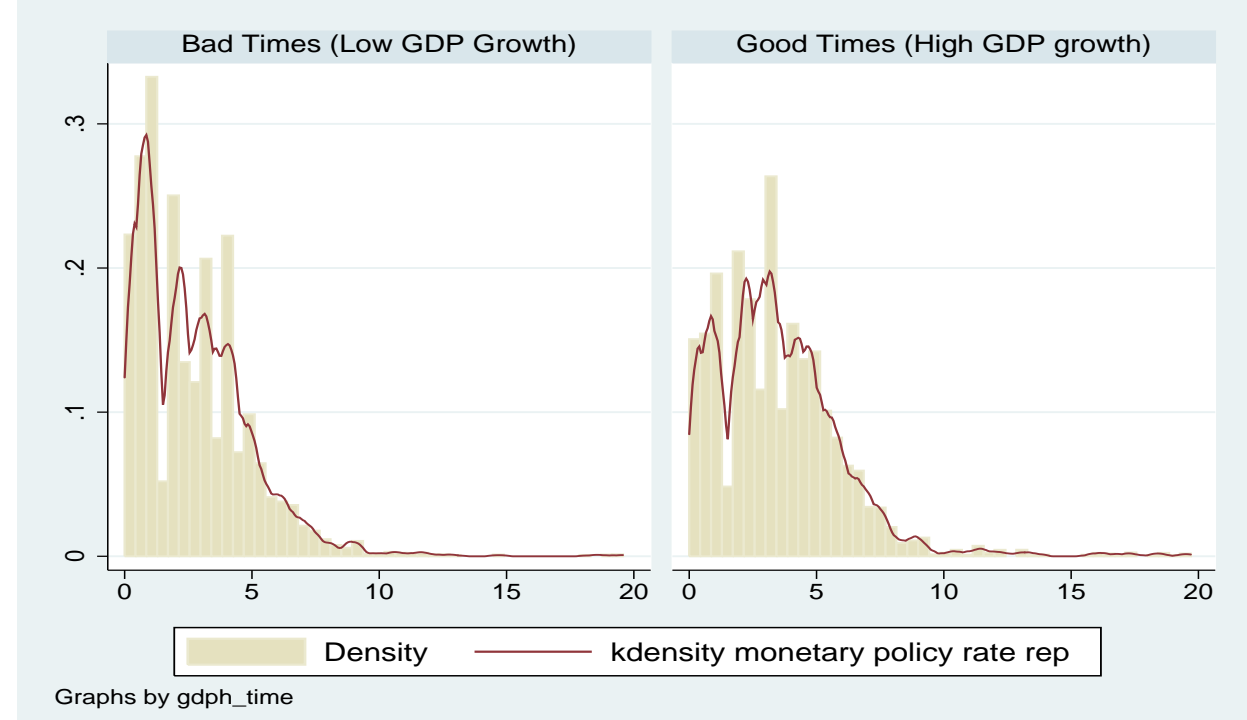

Note: The graphs show the distributions of monetary policy rates in reporting countries for periods of relatively high GDP growth (values are higher than the median) and periods of relatively low GDP growth.

Figure A2.2: Monetary Policy Rate for Currency Appreciation and Depreciation Period

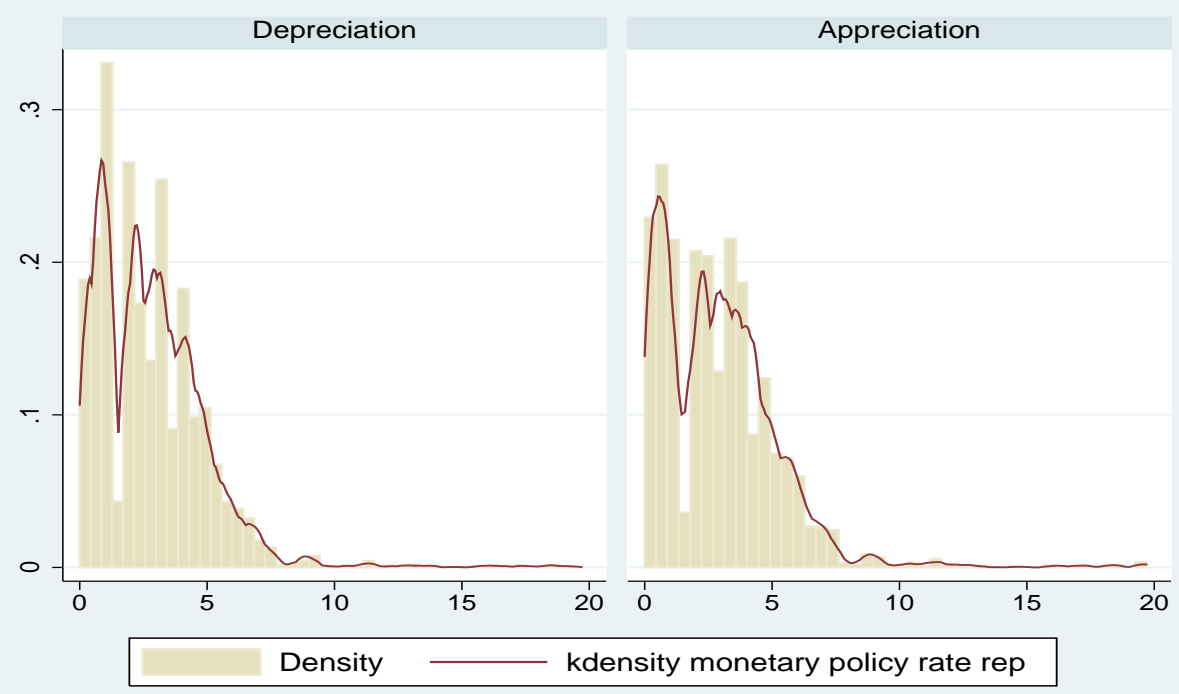

Note: The graph shows the distributions of monetary policy rates in reporting countries for periods of currency appreciation and currency depreciation. 


\section{Appendix 3}

Table A3: A List of Reporting and Counterparty Countries

EME reporting (EME counterparty) takes one if the reporting country is classified as an emerging economy and zero otherwise.

\begin{tabular}{|c|c|c|c|c|c|}
\hline Reporting Country & Observations & EME reporting & Counterparty Country & Observations & EME counterparty \\
\hline AUSTRALIA & 1,467 & 0 & ALGERIA & 456 & 1 \\
\hline AUSTRIA & 3,832 & 0 & ARGENTINA & 1,014 & 1 \\
\hline BELGIUM & 4,034 & 0 & AUSTRALIA & 1,316 & 0 \\
\hline BRAZIL & 819 & 1 & AUSTRIA & 1,389 & 0 \\
\hline CANADA & 2,333 & 0 & BELGIUM & 1,498 & 0 \\
\hline DENMARK & 2,238 & 0 & BOLIVIA & 123 & 1 \\
\hline FINLAND & 1,581 & 0 & BRAZIL & 1,276 & 1 \\
\hline FRANCE & 5,228 & 0 & BULGARIA & 672 & 1 \\
\hline GERMANY & 5,318 & 0 & CANADA & 1,402 & 0 \\
\hline GREECE & 845 & 1 & CHILE & 1,171 & 1 \\
\hline HONG KONG & 2,184 & 1 & CHINA & 1,376 & 1 \\
\hline INDIA & 1,764 & 1 & COLOMBIA & 700 & 1 \\
\hline INDONESIA & 274 & 1 & COTE D'IVOIRE & 231 & 1 \\
\hline IRELAND & 2,265 & 0 & CROATIA & 473 & 1 \\
\hline ITALY & 3,348 & 0 & CYPRUS & 777 & 1 \\
\hline JAPAN & 3,410 & 0 & CZECH REPUBLIC & 951 & 1 \\
\hline KOREA & 2,160 & 0 & DENMARK & 1,394 & 0 \\
\hline LUXEMBURG & 2,549 & 0 & ESTONIA & 122 & 1 \\
\hline MALAYSIA & 866 & 1 & FINLAND & 1,270 & 0 \\
\hline MEXICO & 170 & 1 & FRANCE & 1,636 & 0 \\
\hline NETHERLANDS & 4,094 & 0 & GERMANY & 1,598 & 0 \\
\hline PORTUGAL & 1,479 & 0 & GHANA & 346 & 1 \\
\hline SOUTH AFRICA & 373 & 0 & GREECE & 1,143 & 1 \\
\hline SPAIN & 3,285 & 0 & GUATEMALA & 345 & 1 \\
\hline SWEDEN & 2,227 & 0 & HONG KONG & 1,362 & 1 \\
\hline SWITZERLAND & 5,236 & 0 & HUNGARY & 936 & 1 \\
\hline TURKEY & 794 & 1 & ICELAND & 838 & 0 \\
\hline UNITED KINGDOM & 5,236 & 0 & INDIA & 1,074 & 1 \\
\hline UNITED STATES & 3,889 & 0 & INDONESIA & 1,308 & 1 \\
\hline \multirow[t]{49}{*}{ TOTAL } & 73,298 & 29 & IRELAND & 1,505 & 0 \\
\hline & & & ISRAEL & 1,017 & 1 \\
\hline & & & ITALY & 1,508 & 0 \\
\hline & & & JAMAICA & 231 & 1 \\
\hline & & & JAPAN & 1,561 & 0 \\
\hline & & & JORDAN & 406 & 1 \\
\hline & & & KOREA & 1,134 & 1 \\
\hline & & & KUWAIT & 557 & 1 \\
\hline & & & LATVIA & 73 & 1 \\
\hline & & & LIBYA & 169 & 1 \\
\hline & & & LITHUANIA & 270 & 1 \\
\hline & & & LUXEMBOURG & 1,487 & 0 \\
\hline & & & MALAYSIA & 933 & 1 \\
\hline & & & MAURITIUS & 388 & 1 \\
\hline & & & MEXICO & 1,219 & 1 \\
\hline & & & MOROCCO & 892 & 1 \\
\hline & & & NETHERLANDS & 1,612 & 0 \\
\hline & & & NEW ZEALAND & 901 & 0 \\
\hline & & & NORWAY & 1,391 & 0 \\
\hline & & & OMAN & 500 & 1 \\
\hline & & & PAKISTAN & 707 & 1 \\
\hline & & & PANAMA & 1,097 & 1 \\
\hline & & & PARAGUAY & 341 & 1 \\
\hline & & & PERU & 918 & 1 \\
\hline & & & PHILIPPINES & 1,004 & 1 \\
\hline & & & POLAND & 1,128 & 1 \\
\hline & & & PORTUGAL & 1,295 & 0 \\
\hline & & & QATAR & 564 & 1 \\
\hline & & & ROMANIA & 647 & 1 \\
\hline & & & RUSSIA & 1,314 & 1 \\
\hline & & & SAUDI ARABIA & 1,004 & 1 \\
\hline & & & SENEGAL & 172 & 1 \\
\hline & & & SINGAPORE & 1,483 & 1 \\
\hline & & & SLOVAK REPUBLIC & 555 & 1 \\
\hline & & & SLOVENIA & 582 & 1 \\
\hline & & & SOUTH AFRICA & 1,195 & 1 \\
\hline & & & SPAIN & 1,406 & 0 \\
\hline & & & SRI LANKA & 538 & 1 \\
\hline & & & SWEDEN & 1,393 & 0 \\
\hline & & & SWITZERLAND & 1,595 & 0 \\
\hline & & & TAIWAN & 946 & 1 \\
\hline & & & THAILAND & 940 & 1 \\
\hline & & & TUNISIA & 635 & 1 \\
\hline & & & TURKEY & 1,317 & 1 \\
\hline & & & UKRAINE & 309 & 1 \\
\hline & & & UNITED KINGDOM & 1,652 & 0 \\
\hline & & & UNITED STATES & 1,647 & 0 \\
\hline & & & VENEZUELA & 963 & 1 \\
\hline & & & TOTAL & 73,298 & 77 \\
\hline
\end{tabular}

